\title{
犬下顎骨の発育に関する実験的研究
}

九州歯科大学第工補経学教室（指導：坪根政治教授）

九州歯科大学口腔組織学教室（指導 : 三枝 博教授）

$$
\text { 大学院生神田昭司 }
$$

（昭和 44 年 8 月 21 日受理）

（本論文の要旨は昭和44年 5 月24日第28回九州歯科学会総会にて発表したものである）

\section{A MORPHOLOGICAL CHANGES OF THE LOG'S MANDIBLE CAUSED WITH THOROUGH EXCISION OF M.MASSETER}

By

\author{
Shoji KANDA
}

First Department of Prosthetics, (Director : Prof. Masaharu TSUBONE)

Department of Oral-histology, (Director : Prof. Hiroshi SAEGUSA)

Kyushu Dental College, Kitakyushu, Japan

An experimental study was conducted with dogs into how the functional decline due to complete removal of $\mathrm{m}$. masseter on one side affects the morphological growth of the mandible. The dogs used for the experiment were 1.5 to 2 months old ( 1.5 to $3.2 \mathrm{~kg}$.) and were operated on the left side, with the right side as control. Forty dogs were divided into seven groups, Group I undergoing the experiment for one month, Group 7 for seven months and were observed by macroscopic, radiographical, osteometrical, and split. ting-line methods. The findings are summarized as follows:

1. In Group I, osseous proliferous hypertrophy was observed in the masseteric fossa and the crest of the condyloid process on the experimental side. Radiographically it was found that the osteotrabecula were arranged irregularly and loosely and the splitting lines were irregular. The osseous proliferous hypertrophy increased with the passage at time, reaching the maximum in Group 4. Radiographical examination disclosed increasingly obscure pictures, and splitting-line examination revealed an expansion of the area of irregular lines. But in Groups 5 to 7, the surface of the massetric fossa and the crest of the condyloid process tended to become smooth in the same way as on the control side, and radiographical penetration grew more difficult, while the irregular lines tended to become normal.

2. No difference was observed between the two sides in the eruption of teeth, but the formation of interdental spaces between premolars came later on the experiemntal side. $\mathrm{X}$-ray penetrated through the interradicular alveolar septum of the fourth premolar and the first molar more distinctly on the experimental side.

3. In all groups, a reduction in distance or angle was observed on the experimental side in the length of the mandible (if - cd, cl. cm. goc. crc, crd), the height of the coronoid process (crd - gov, cd -crd), the height of the condyloid process (cd-gov, 
(cl-gov, cm-gov), the length of the condyloid process ( $\mathrm{cm}-\mathrm{cl})$, the body angle of the mandible, the inclination angle of the condyloid process, the height of the mandible body of premolars $\left(\overline{a_{2}}-a^{\prime} \bar{p}_{2}, a \overline{p_{3}}-a^{\prime} \bar{p}_{3}, a \overline{p_{4}}-a^{\prime} \overline{p_{4}}\right)$. This was conspicuous especially for if-goc, crd-gov, cd-gov, cl-gov, cm-gov, $\mathrm{cm}-\mathrm{cl}$, the body angle of the mandible, and the inclination angle of the condyloid process.

An increase was observed in the height of the mandible body of the molars, the angle of the processus coronoideus, and the height of the edge of the incisors.

The reduction in the length and angle of the various' parts are manifestations of functional morphology due to the incision of the $\mathrm{m}$. masseter. The osseous proliferous hypertrophy in the masseteric fossa and the mandible body of the molars physiological defense reaction to the incision.

\section{緒 言}

下頡骨の形態発育については, てれまで解剖学, 矯正 学, 補綴学およびその他の分野よりいろんな方法にて研 究されてきた。

下顎骨は咀嚼器官として機能的にきわめて特異的なも のであり，形態上から複雑性をおびているすのである. その形態発育に関するこれまでの研究結果の趨勢は, 咀 嚼による機能形態であるという。したがって咀嚼に最も 関与する咀嚼筋は，その形態発育に与える影響が一番大 であると推定されている。しかし，乙れまで行なわれて きた実験的研究の多くは，歯牙の抜去という形で行なわ れており，咀嚼に最も強く働く咀嚼筋についての研究 は Scott (1938), 対木40) (1950) およびAvis2) (1961) の報告があるのみである.

ちなみに, 従来加らの下顎骨の形態発育についての研 究方法をあげてみる之,

1）発育過程におりる各段階の模型図を作りそれを重 放合わ女，ある特定部位間の距離の増加，減少を観察す る方法.

2 ）罘骨内に，人工的に金属鋲を装着し，ある一定期 間後その 2 点間の直線距離を測るという，いわゆる標識 装着法400)

3）錯酸鉛の生体染色法により, 硬組織の発育過程を 沈着した鉊線により時間的, 量的に観察する組織学的検 索法28,41.42).

4) 分裂線法により発育段階の各時期の線系抢よび不 整裂線により，骨の発育方向，および発育点を観察する 方法 $9,17,18.21,25,30,39$ )

5）古くより行なわれ，現在むなお行なわれている方 法として，各種年令の顎骨について解剖学的に特徵ある 渚点間の直線距離を計測して骨形成, および発育の程度
を数值で示す計測法,

6) 機能を原因とみなし，結果を形態に見出そうとす るむので, 䨑牙の発育之咀嚼機能とが顎骨の形態発育 に重大な影響を与えるという立場から，乳歯の早期抜去 および永久雬胚の摘出による下顎骨の形態変化を調べる 方法である1,20,31,38,40,41,42).

さらに，乙れと同じ立場から咬筋剥離実験がある。

1)〜5) は単なる正常な顎骨の発育を知るためす方 法である.

6) は機能適応説という観点からの方法で，喝嚼運動 に，ある障碍すな和ち咀嚼力失調を与えた場合，それに より引き起される形態異常は，その部の盟嚼力の失調に より形づくられたあのであるとしている。この立場から 堤41.42) (1953), 雨禁1) (1964) 高橋36) (1936), 対木 40)（1950），等 $3,19,20,33,43)$ の乳米扰よび永久歯肧の拢去 による報告がある。

堤は，実験側が対照側に比し，下靧骨の全長，上行枝 高径, 地平部高径; 地平部幅徍, さら吃下顎小頭長径に それぞれ距離の短縮をみたと報告した。雨燓は，下顎骨 の全長, 関節突起高径, 関節頭の幅径, 下顎枝幅径求よ び下顎体の高さ䎲えれぞれ变化が認められたさ報告して いる.

一方, 高橋, 対木等の報告によればなんら変化が認め られなかったとのべている。

対木40)の試みた咬筋剥離実験をみるに，咬筋停止部の 一部剥離で，かつ筋の再附着を防止するために金属簿を 挿人し：さらに金属鋲の標識を顎骨内に装着したもので ある，その報告によれば，咬筋の機能力は下頇骨の形態 発育, とくに隅角部の発育に対する影響が大であると述 べている.

しかし，金属䈃の插入拉よび金属鋲の装着は病理的変 
化，すなわち骨の吸収を発現せしめるもの统あるら， 咬筋の一部剥離という筋機能力失調によりひき起された 形態変化のすべてがはたして筋の機能力の失調によるも のであるか否かは疑問である。

そとて，著者は機能を原因とみなし，結果を形態に見 出そうとする機能適応説の立場より, 先人の実験方法を さらに推し進めて咀嚼運動に最も強く働く咀嚼筋機能力 の除去すなねち咬筋の完全なる切除による機能失調が 下顎骨の形態発弆によ゙のような影響を执よぼすか動物実 験を行ない検討し，いささかの所見を得たのでその詳細 を報告する。

\section{実 験 材 料}

実験材料としては，日本産雑種犬で，乳曾列の萠出完 了直後12.24)すなわ方, 生後 $1.5 \sim 2$ 力月, 体重 $1.5 \sim 3.2$ $\mathrm{kg}$ の仔犬72匹を実験に供した。

後述方法の㕮筋切除が，下顎骨の発育におよぼす形態 の諸変化を経時的に観察するため, 実験動物を実験期間 により術後1カ月から７カ月までとした。咬筋切除手術 を施される本時期の奻犬は，いろいろの疾病に対して抵 抗力が弱いこと，手術により個体におよぼす損傷がかな り大きいため，表卫に示したように28匹という多数犬が 病死した25). これら手術による失敗, 病死あるいは, 先

表 1

\begin{tabular}{|c|c|c|c|c|}
\hline $\begin{array}{l}\text { 実験番号 } \\
\text { (No.) }\end{array}$ & 性 & $\begin{array}{l}\text { 体重 } \\
(\mathrm{kg})\end{array}$ & 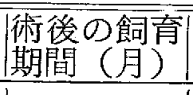 & 考 \\
\hline 1 & $\hat{\delta}$ & 2.8 & 5 & \\
\hline 2 & $\hat{o}$ & 2.7 & 5 & \\
\hline 3 & 우 & 2.6 & 5 & \\
\hline 4 & $\hat{\sigma}$ & 1.8 & 3 & 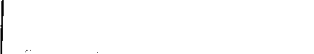 \\
\hline 5 & $q$ & 1.8 & 7 & \\
\hline 6 & 우 & 2.0 & 1 & . \\
\hline 7 & 우 & 1.9 & & 病死（術後性肺炎） \\
\hline 8 & $\uparrow$ & 1.7 & & 病死 (術後性肺炎) \\
\hline 9 & 우 & 2.2 & 7 & \\
\hline 1.0 & 우 & 2.1 & & 病死 (術後性肺炎) \\
\hline 11 & 우 & 2.6 & & 病死 (二 次 感 染) \\
\hline 12 & $\hat{\delta}$ & 1.9 & 1 & \\
\hline 13 & 우 & 2.3 & & 病死（術後性肺炎） \\
\hline 14 & 今 & 3.0 & 1 & \\
\hline 15 & 占 & 2.6 & & 逃亡 \\
\hline 16 & $\hat{\delta}$ & 2.5 & & 逃亡 \\
\hline 17 & 우 & 1.9 & & 病死（術後性肺炎） \\
\hline 18 & 占 & 1.6 & & 病死（術後性肺炎） \\
\hline 19 & $\hat{\delta}$ & 2.6 & 7 & \\
\hline 20 & q & 2.0 & 7 & \\
\hline
\end{tabular}

\begin{tabular}{|c|c|c|c|c|}
\hline 2] & $\delta$ & 3.0 & & 病死(ジステンバー) \\
\hline 22 & 우 & 2.3 & & 病死(ジステンバー) \\
\hline 23 & ㅇ & 1.9 & & 病死(ジステンバー) \\
\hline 24 & 우 & 2.0 & & 病死(ジステンバ一) \\
\hline 25 & q & 2.3 & & 病死(金句 虫 症) \\
\hline 26 & $\hat{\delta}$ & 2.4 & 1 & \\
\hline 27 & $q$ & 1.8 & & 逃亡 \\
\hline 28 & $\hat{0}$ & 2.4 & & 病死(鉤 虫 症) \\
\hline 29 & $\delta$ & 1.9 & & 病死 (ジステンバー) \\
\hline 30 & $\hat{o}$ & 2.3 & 4 & \\
\hline 31 & 9 & 2.5 & 7 & \\
\hline 32 & 우 & 2.3 & & 病死 \\
\hline 33 & 우 & 2.3 & & 病死 \\
\hline 34 & 今 & 2.8 & 3 & 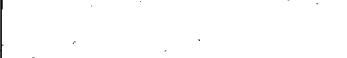 \\
\hline 35 & $\uparrow$ & 2.3 & & 病死 \\
\hline 36 & q & 2.5 & & 病死 \\
\hline 37 & 우 & 1.9 & 7 & 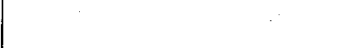 \\
\hline 38 & q & 2.8 & & 病死 \\
\hline 39 & $\hat{0}$ & 2.9 & & 病死(二 次 感 染) \\
\hline 40 & 우 & 2.3 & 7 & \\
\hline 41 & 우 & 3.1 & 7 & \\
\hline 42 & 우 & 2.8 & & 病死(氺 毒 症) \\
\hline 43 & 우 & 3.2 & 7 & $\cdot$ \\
\hline 44 & 우 & 2.9 & 7 & i \\
\hline 45 & 우 & 2.4 & 4 & \\
\hline 46 & 우 & 2.2 & 6 & \\
\hline 47 & 우 & 1.8 & 6 & \\
\hline 48 & 우 & 2.3 & 4 & \\
\hline 49 & 우 & 2.8 & 6 & \\
\hline 50 & $\hat{\circ}$ & 2.2 & & 病死 \\
\hline 51 & $\hat{o}$ & 1.8 & & 病死 \\
\hline 52 & 우 & 2.1 & & 病死 \\
\hline 53 & $\hat{\delta}$ & 1.5 & & 病死 \\
\hline 54 & 우 & 2.7 & 6 & $\therefore \quad$ \\
\hline 55 & $\hat{o}$ & 2.5 & 6 & 顎 拘 縮 症 \\
\hline 56 & $\hat{o}$ & 1.5 & & 病死（尿 毒 症) \\
\hline 57 & 우 & 2.8 & 2 & \\
\hline 58 & \$ & 3.1 & & 病死 \\
\hline 59 & 우 & 2.8 & 2 & 病死（皮慮炎上り一 \\
\hline 60 & 官 & 3.1 & : & 次感染 \\
\hline 61 & 우 & 2.2 & 5 & $\cdots$ \\
\hline 62 & 우 & 1.9 & 1. & . \\
\hline$\because$ & 우 & 2.5 & 5 & \\
\hline 64 & 今 & 2.8 & 4 & 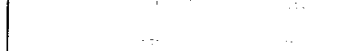 \\
\hline 65 & $\uparrow$ & 2.5 & 4 & \\
\hline 56 & $\hat{\jmath}$ & 3. J & 3 & 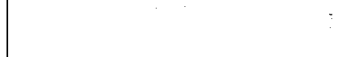 \\
\hline 57 & $\hat{\delta}$ & 3.0 & 3 & . \\
\hline 88 & $\hat{o}$ & 2.7 & 3 & \\
\hline
\end{tabular}




\begin{tabular}{l|l|l|l|l|}
69 & 今 & 27. & 2 \\
70 & ㅇ & 3.8 & 2 \\
71. & ㅇ & 2.7 & 6 \\
72 & 1 & 2.2 & 2 & \\
\hline
\end{tabular}

天的歯牙欠損37)のあるものは，正確さを期すため観察対 照から除外した。したがって，実際観察に供したものは 40例之なる。 それらは表 2 に示すように，実験期間によ り 7 groups に分けた。すなわち, 術後コカから7カ月 をそれぞれ group 1.から group 7.とした。このう 5, 実験番号 No. ] 3, No. $19 \sim 20$, No. $46 \sim 47$, No. 6l〜 62, No. 66〜67, No. 68〜70 の一連はそれぞ 机同腹のものである。出生年月日の明白なもの32例，不 明なあの8例であった。後者のあのについては，乳歯列 の萠出状態，およびX線により，乳歯根さらには継承永 久歯芽の発育状態を調べ，乳霜列の萠出完了直後である 事を確かめた上で実験に供した。なお，性差による区別 は行なわなかった。

表 2

\begin{tabular}{|c|c|c|c|c|c|c|c|c|c|c|}
\hline 奏験期間 & \multicolumn{3}{|c|}{ 実 } & \multicolumn{2}{|c|}{ 験 } & 番 & \multicolumn{3}{|c|}{ 号 } & 計 \\
\hline 」.ケ月 & 6 & 12 & 14 & 26 & 62 & & & & & 5 \\
\hline 2 & 57 & 59 & 69 & 70 & 72 & & & & & 5 \\
\hline 3 & 4 & 34 & 66 & 67 & 68 & & & & & 5 \\
\hline 4 & 30 & 45 & 48 & 64 & 65 & & & & & 5 \\
\hline 5 & 1 & 2 & 3 & 61. & 63 & & & & & 5 \\
\hline 6 & 46 & 47 & 49 & 54 & 71 & & & & & 5 \\
\hline 7 & 5 & 9 & 19 & 20 & 31. & 37 & $4 \mathrm{O}^{\prime}$ & 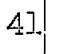 & $43 \quad 44$ & 10 \\
\hline
\end{tabular}

実 験 方 法

実験当初，数匹については，ラボナールAの静脉内注 射による全身麻酔にて行ない，その後麻酔用エーテルの 気管内挿入法による全身麻酔に切り替えたが, 術後経過 が非常に悪く，実験番号20よりペント・バルビタ一ル・ ナトリウム $0.4 \mathrm{ml} / \mathrm{kg}$ (body weight) の静脉 内注射に よる全身麻酔のもとで行なった。

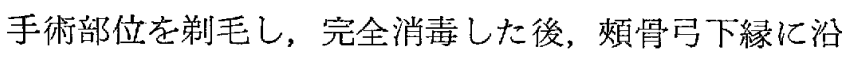
って $4 \mathrm{~cm}$ に执よぶ皮膚切開を加え，咬筋の賽骨弓起始 部より停止部まで完全に露出し，最初に咬筋表層の起始 部を剥離した，咬筋の中層，媣層はともに煩骨与の腹側 棱および内側面から起っているので，起始部を完全剥離 するため煩骨弓のほぼ全体，すなわち頓骨側頭突起後方 から関節窝前方までを切断, 切除してから, 両層の起始 部を完全に剥離した。ささらに，下顎枝に沿って咬筋の全 層を骨面より骨膜と共に剥離し，咬筋の停止部である咬
筋窝，下顎骨隅角部外側，腹側の両面および，角突起部 までを丁寧かつ完全に剥離切除した，咬筋の全層が完全 に切除されたのを確かめ，通法のごとく縫合し手術を完 了した。術後懸濁水性ペニシリン G, 30万単位を臂部に 筋注し，7〜10日継続した. 術後1.0〜1.5日で手術部は肉 眼的に完全に治癒した，実験期間中は可及的にすべての 動物が，ほぼ同じ条件のもと，専用ケージで飼育した。 予定飼育期間满了に至れば，ペント・バルビタール・ ナトリウムで薬殺し, 肉眼的観察, 製 骨標本による計 測，X線による観察，ならびに分裂線法による観察に供 した.

これら実験動物において左側を実験側, 右側を対照側 とした.

\section{1）計測について}

(1) 計测点求よび計测部位.（模式図 1. a. b. c.) 計測点招よび計测部位は大部分斎藤29), 雨森1) 両者の 方法に準じ，一部は人頭蓋計測法13)を準用し設定した。 各標本群の計测点の位置を一定にするための顎固定器を プラスチックおよび金属により適当に工夫作製した。す
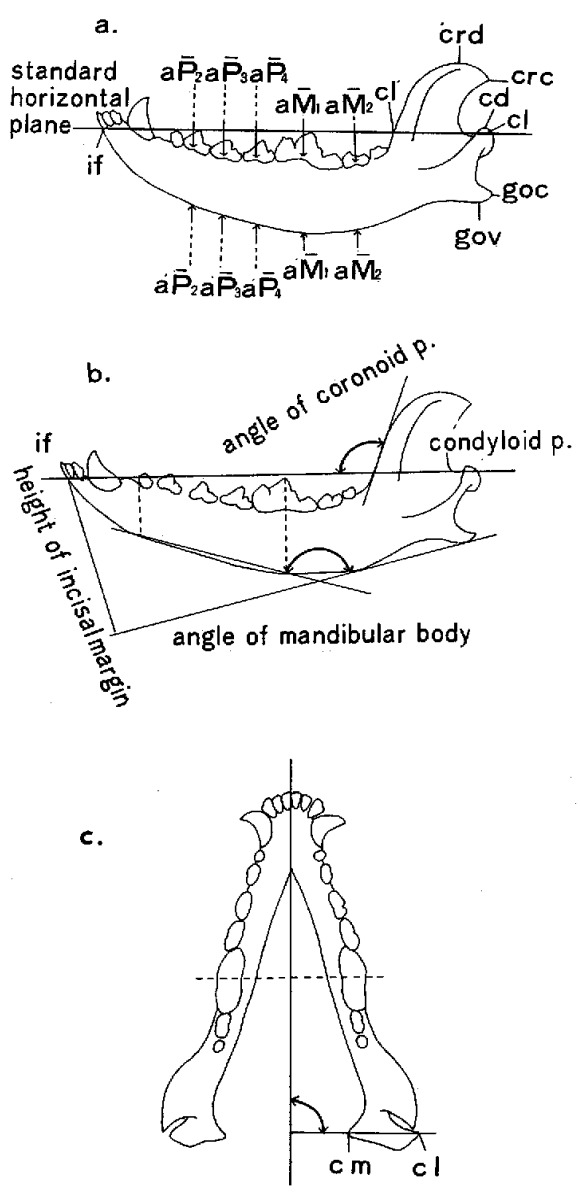

図 1. a . b， c. 計测点および計測部位 
なわち，左右側の関節頭最外側点 $\mathrm{cl}$ と，下顎結合の最 屯前方に突出した点 if 03 点を結ふ心仮想面（標準水平 面）が基準台面に平行になるように固定し，同一条件下 の屯とで次の計測点を決定した。（四 I，a，b. c.)

a. Infradentale. (if) : 下顎結合で最も前方に突出し た点

b. Condylion laterale (cl) : 関節頭の最外側点

c. Coronion dorsale (crd) : 筋突起の最背方点

d. Coronion caudale ( $\mathrm{crc}$ ) : 筋突起の最尾方点

e. Condylion dorsale (cd) : 関節頭の最背方点

f. Condylion mediale $(\mathrm{cm})$ : 関節頭の最内方点

g. Gonion ventrale (gov) : 下顎角の最腹方点

h. Gonion caudale (goc) : 下顎角の最尾方点

i. $\quad \overline{\mathrm{P}}_{2}, \quad \mathrm{a}^{\prime} \overline{\mathrm{P}_{2}}, \quad \mathrm{a} \overline{\mathrm{P}_{3}}, \quad \mathrm{a}^{\prime} \overline{\mathrm{P}_{8}}, \quad \mathrm{a \textrm {P } _ { 4 }}, \quad \mathrm{a}^{\overline{\mathrm{P}_{4}}}, \quad \mathrm{a} \overline{\mathrm{M}}_{1}, \mathrm{a}^{\prime} \overline{\mathrm{M}}_{1}$, $\mathrm{a} \overline{\mathrm{M}}_{2}, \mathrm{a}^{\prime} \overline{\mathrm{M}}_{2}$, （左右両倒）

$\mathrm{a} \overline{\mathrm{P}}_{2}$ と $\mathrm{a}^{\prime} \overline{\mathrm{P}}_{2}$ を例にとれば，下䪽第 2 小曰歯の近，遠心 根分岐部の煩側 (外側) 歯槽縁上の中点を $\mathrm{a} \overline{\mathrm{P}_{2}}$ とし た。標準水平面に点 $\mathrm{aP}_{2}$ を通る垂線を立て，それか下 顎骨下縁と交わる点を $\mathrm{a}^{\prime} \mathrm{P}_{2}$ とした，以下同様にして $\mathrm{a} \overline{\mathrm{P}_{3}}, \quad \mathrm{a}^{\prime} \overline{\mathrm{P}_{3}}, \quad \mathrm{a \textrm {P } _ { 4 }}, \quad \mathrm{a}^{\prime} \overline{\mathrm{P}_{4}}, \quad \mathrm{a} \overline{\mathrm{M}}_{1}, \quad \mathrm{a}^{\prime} \overline{\mathrm{M}}_{1}, \quad \mathrm{a} \overline{\mathrm{M}}_{2}, \quad \mathrm{a}^{\prime} \overline{\mathrm{M}}_{2}$ につ いて求めた。

j. $\mathrm{cl}^{\prime}$ ：標準線（前記 標準 水平面に従って引かれた

線）が筋突起前縁と交わって出来る交線の最前 方点.

以上の計測点を製骨標本上に記し，下記の 2 点間の直 線距離を計測した。計測にはノギス (1/20mm) を用い た。
(1). $\mathrm{i} \hat{\mathrm{f}}-\mathrm{cl}$.
(2). if $-\mathrm{cd}$.
(3). if $-\mathrm{cm}$.
(4). if -goc.

(5) if-crc.

(6). if $-\mathrm{crd}$.

(7). $\mathrm{cd}-\mathrm{crd}$

(8). crd-

gov. (9). $\mathrm{cl}-$ gov. (10). $\mathrm{cd}-\mathrm{gov}$. (11). $\mathrm{cm}-$ gov. (12). $\mathrm{cm}-\mathrm{cl}$. (18). $\mathrm{cl}-\mathrm{cl}^{\prime}$. (14). $\overline{\mathrm{a}} \overline{\mathrm{P}_{2}}-\mathrm{a}^{\overline{\mathrm{P}_{2}}}$. (15). $\mathrm{a} \overline{\mathrm{P}_{3}}-\mathrm{a}^{\prime} \mathrm{P}_{8}$. (16). $a \bar{P}_{4}-a^{\prime} \bar{P}_{4}$. (17). $a \bar{M}_{1}-a^{\prime} \bar{M}_{1}$. (18). $a \bar{M}_{2}-a^{\prime} \bar{M}_{2}$ 計測は，数回行ない，その平均值をむって㬰測值とし た。

下記の下顎枝角，下顎体角，切蒾縁高，関節頭傾斜角 は後術のX線撮影により間接的に計測を行なった。

(19). Angle of coronoid process

筋突起前縁に沿った接線之標準線之のなす角度.

(20). Angle of mandibular body.

角突起下縁と下顎体後方下縁とを結ふ線を角突起下縁

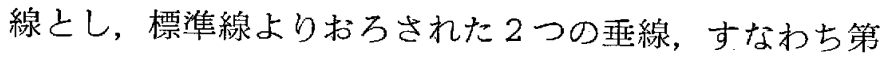

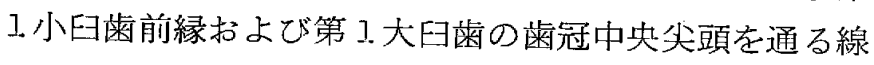
が下顎骨下縁と交わる2 点を結ぶ楾を下顎下縁線とし，
この両下縁線のなす角度。

(22) Height of incisal margin

角突起下縁線の延長線から点 if.に扔ろされた垂線距 離.

(22. Inclination angle of condyloid process.

左右側の第1.大正歯中央尖頭を結ぶ線の中点と点 if. を結んだ延長線が左右側それぞれの関節頭長軸（cl一 $\mathrm{cm}$ ）の延長線上交わる角度.

なお，第】小曰歯および第】大曰歯の未萠出の標本は 計測より除外した。

\section{2） $\mathrm{x}$ 線について}

(1) 撮影方法

下顎骨体の外側面を上方に向け，関節頭内側点 $(\mathrm{cm})$ と下顎結合部とを同一平面上（カセッテ）に置き，第 1 大兒歯中央尖頭と前記 $\mathrm{a}^{\prime} \overline{\mathrm{M}}_{1}$ とをカセッテより等距離 になるように固定した。

\section{(2). 撮影条件}

管電压 $45 \mathrm{kv}$ ，管電流 $100 \mathrm{~mA}$. 時間 $1 / 15 \mathrm{sec}$ で, F.

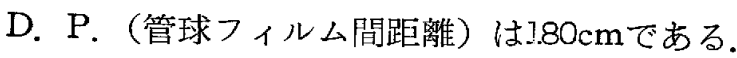

\section{3）分裂線法について}

標本に附着する軟組織を可及的完全に剥離し，次いで $10 \%$ Formalin 液にて固定した後, $5 \% \mathrm{HCl}$ による電 気脱灰法を施した。分裂線形成に必要な適性脱灰の判定 はX線にて行なった。脱灭完了後は，中和，水洗し，穿 刺にうつった，穿刺針は，月例別に応じ直径 $0.5 \sim 0.9$ $\mathrm{mm}$ のむのを用い, 穿刺針の尖端に墨汁を浸し，骨表面 に対し直角に穿刺した，穿刺が終れば余分の墨汁を拭い おとし，80\% Alcohol 中に投じ固定保存した。なお， 穿針用墨汁は良質の毛筆用墨汁を踈の濾紙にて濾過した あのである.

\section{1) 肉眼的所見}

(1). 剖検所見

実験犬のすべてにおいて，実験側の咬筋切除領域は筋 肉に代ってはなはだ液状に富む結合組織性構造物によっ て厚く被われていた。しかし，咬筋存在ほどの盛り上り は無汃った。該構造物を剥離すると，実験時剥離した骨 膜の再生が見られた。，また，実験側の側頭筋や対照側の 咬筋, 側頭筋などに筋切除による代償性の変化は認めら れなかった。

(2). 製骨標本所見

Group I.から Group 7 亿至る顎の発育に伴う実験側上 対照側問の形態変化は，おもに下顎枝の各部に認められ る. 以下, Group 】ょり随時述べることにする。 


\section{Group 1.（生後 3力月）}

萠出歯牙の状態はいまだ乳蒾列で歯式で示すと次のよ うになる。

\section{$\mathrm{m}_{1-3} \mathrm{ci}_{1-3} \mid \mathrm{i}_{1-3} \mathrm{~cm} \mathrm{~m}_{1-3}$}

対照側 筋㔖起を除いた下顎枝の各部，すなわち関節突 起，角突起，咬筋䆚，関節突起稯などは，ほば発育形に 近い形状をすでに呈している，筋突起の前縁の発育は， 不充分で発巟途上の様相を旺し該部から下顎体にかけ海 綿状あるいは粗造感を現わしている。

実験側 咬筋窝には，すでに骨の増生が見られ，窝自体 いくらか浅く粗造な骨面を示す，筋突起の前縁の発育は 対照側上りあ悪い，したがって，筋突起の前後的幅径が 前者より短く感じられる，角突起の発育む悪く，発育不 全を思わしわる形状である，その他， $\overline{\mathbf{M}}_{\mathbf{1}}$ 部の骨体が右 側に比して，内外的拈よび上下的に骨の肥厚が観察され る.

\section{Group 2.（生後 4力月）}

歯列には永久歯の萠出がみられ，所謂混合霜列の始ま りを示す，歯式は次のとおりである.

\section{$\overline{\mathrm{M}}_{1} \mathrm{~m}_{1-3 \mathrm{cis}} \mathrm{I}_{1-2} \mid \mathrm{I}_{1-2} \mathrm{i}_{3} \mathrm{~cm}_{1-3} \mathrm{M}_{1}$}

対照側 下顎枝の各部は，group 」より著しく増大し た形態を示すが，筋突起の前縁から骨体の後方部にかけ てはいぜんとして骨の増策過程を示す如く，海綿状の骨 面を呈している，また，咬筋窩の後方加ら関節突起棱に かけての骨面も粗造，あるいは海綿状を呈している，関 節頭面には，大小の不規則な小孔がみられる。

実験側 咬筋附着部は，group I. 上同じく，軽 度の骨増 生がみられるが，その他に，内翼突筋附着部む舌側方向 に結節状に肥厚している，さらに，関節突起稜の肥厚が 観察される．それらの骨面はいずれす粗造である。一 方，角突起は，発育不全を思柇孔る形態異常を呈し， 前期に比し著明になっている，関節頭面には対照側と同 じく，大小の不規則な小孔が見られるが，関節頭の長径 が短縮し発育不全の様相を呈している。なお， $\overline{\mathrm{M}}_{1}$ 骨体 部は前 group 同様，内外的扰よび上下的に肥厚してい る.

Group 3. (生後 5 力月)

萠出歯牙の状態は,

$$
\overline{\mathrm{M}_{1-2} \mathrm{~m}_{2-3} \mathrm{P}_{1} \mathrm{C}} \overline{\mathrm{I}_{1-3}} \mid \mathrm{I}_{1-3} \mathrm{CP}_{1} \mathrm{~m}_{2-3} \mathrm{M}_{1-2}
$$

で未まだ乳蒾が混在している。

対照側 筋突起の前縁， とくに内側前縁が前群に続いて 発育不全で，海綿状の学面を示している，また，関節頭 の前外側および内側からそれぞれ関節突起稜および下頜 孔後方にかけての骨面も海綿状を呈している。ささらに，
内翼突筋附着部向やや肥厚し，粗造骨面をなしている. 関節頭面には前群と同じく，不規則な小孔が存在してい る.

実験側 筋突起の内側前縁は，対照側之同様発育不全で 海綿状骨面を示し，関節頭の前外側抽よび内側の海綿状 骨面は対照側に比しその領域がやや狭くなっており，関 節頭から下顎切痕にかけての切れ込みが鋭くなってい る。 また，関節頭の長径的発育も目立って悪い．角突起 の発育不全は，顕著で丸味を示し下顎隅角よりの彎曲面 上に僅かに突出している程度である. したがって, 内翼 突筋の附着部は，下顎孔直下に見られ，下顎孔自体屯い くらか対照側に比して前方に移動している，一方，関節 突起棱の肥厚が前 group よりあ著しく, 咬筋窩の骨增 生之相俟って浅くなっている，したがって，咬筋䆚部 の骨厚径は対照側に比してはなはだ厚い，(図2）。

b. )。咬筋窩および関節突起稜の肥愿増大により咬筋曧

a.

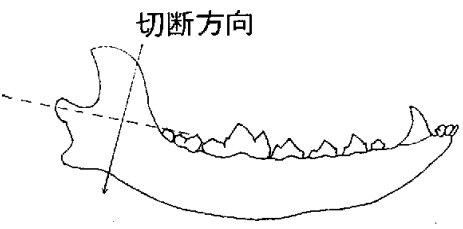

b.
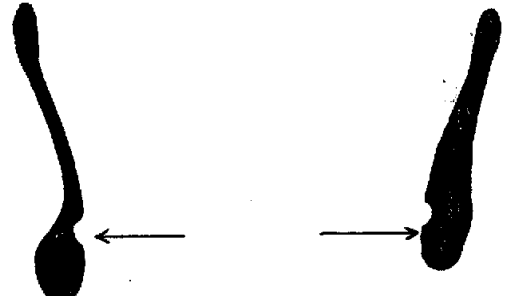

図 2.下顎孔後部断面図 (術後 7 力月)

a. 下顎孔後部の下顓枝切断方向を示す

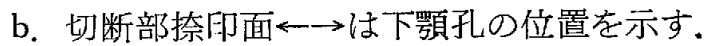

$\mathrm{Cl}$ と $\mathrm{M}_{3}$ 咬合面を結ぶ線（破線）より下顎孔後縁部 を通る垂線（実線）は切断方向を示す。

の下方は凹凸がはげしく，粗造面を呈している． $\overline{\mathbf{M}}_{1}$ 骨 体部の内外的および上下的肥厚も発育に応じ増大してい る.

Group 4. (生後6力月)

歯牙の萠出状態は,

$$
\overline{\mathrm{M}_{1-3} \mathrm{P}_{1-4} \mathrm{CI}_{1-3} \mid \mathrm{I}_{1-3} \mathrm{CP}_{1-4} \mathrm{M}_{1-3}}
$$

で歯列の全部が永久㐘に化している，乳茵，永久歯の交 換過程に括いて，実験側と対照側間の差はほとんぞ認め られない。

対照側 筋突起前縁は $\bar{M}_{\mathbf{3}}$ の萠出に伴い成育形態を整え ているが，いまだに前縁下面に海綿状の骨面が見られ 
る. 関節頭の内側および前外側の骨面屯海綿状から粗造 感に変化しているが，関節頭から下頡切痕にいたる切 れ込みが鋭くなって扣り，完全に関節頭面を遊離させて いる。また，角突起の内側基底部にはっきりとした瑇様 の凹線が見られる。

実験側 $\overline{\mathrm{M}}_{\mathbf{3}}$ の萠出香見られるが筋笑起の前後発育が対 照側よりすやや悪く，海綿状执よび粗面域が広い；角㔖 起は単なる凹凸状あるいは結節状亡して現われてい る. 関節突起稜は，凹凹に富み粗面構造を呈している. 関節突起の長佳的発育ががり悪く，全体的形状が異な っている.さらに，関節突起前縁から筋突起にかけての 下顎切痕の彎曲がやや不規則な傾向を帯びている。

(図 3. a. b.)

a.

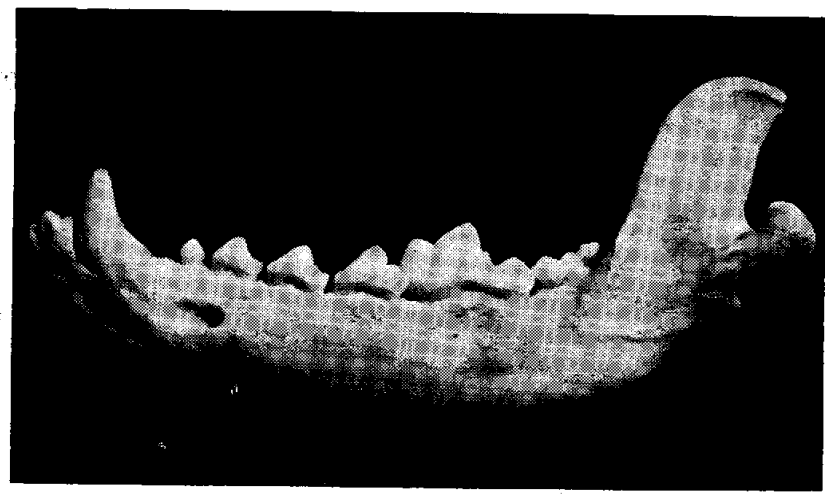

b.

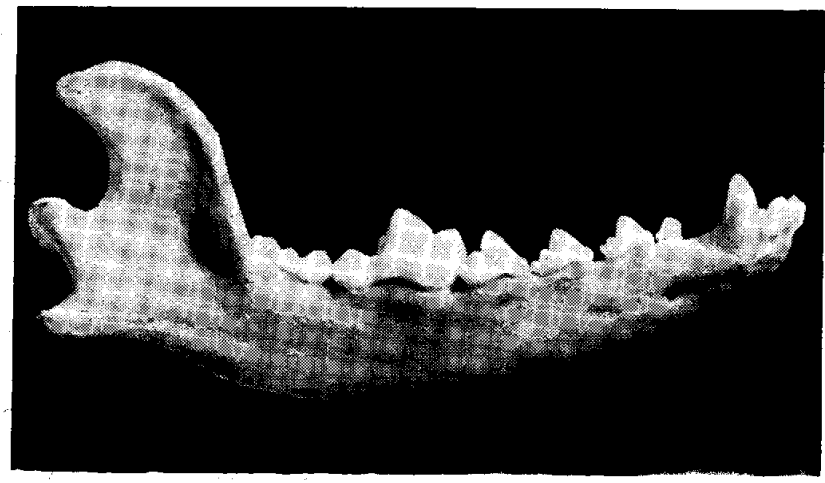

国 3. a. b. 術後 4 力月の製骨標本，a，垁験側.

b. 対照側

\section{Group 5. (生後 7 力月)}

刘照側 本群に打いて，はじめて筋㔖起前緣が成育形態 を現わし，平滑な骨面を呈している。前群までに見られ たその他の下顎枝各部の海綿状あるいは粗造骨面はほ上 んど消失して平滑になっている，角突起の内側基底部に みられた溝様の回線むかなり浅くなっている，また，関 節頭表面の不規則な小孔もほとんど消失している，歯列 弓に打いてはじめて小罒歯部の歯間離開が実験側に比し 著明にみられる。

実験側 咬箭裔および関節突起稜は，骨増生により粗造
骨面を示しているが，関節頭面の小孔は対照側と同じく 消失している。

Group 6. 7.（生後8，9力月）

対照側 Group 5，の所見とほとんよ゙変りはない.

実験側 咬筋窩およびその周辺の骨面構造は，前群とほ とんよ゙変りないが，角突起の発育不全により下顎枝全体 の形状が対照側に比し，貧弱にして，いかにも機能減退 による発育不全の様相を著明に現わしている，対照側の group 5.でみ方れた小臼菌部の歯冠離開が，この期に はじめて観察される。（図 4.a.b.）

a.

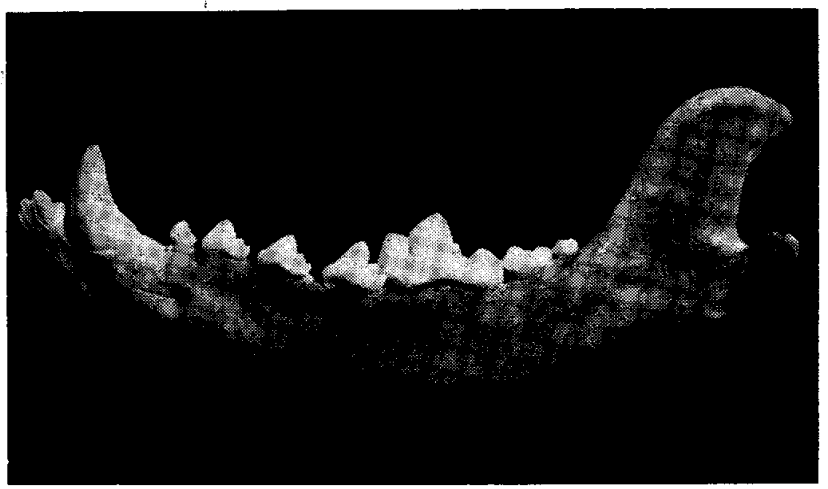

b.

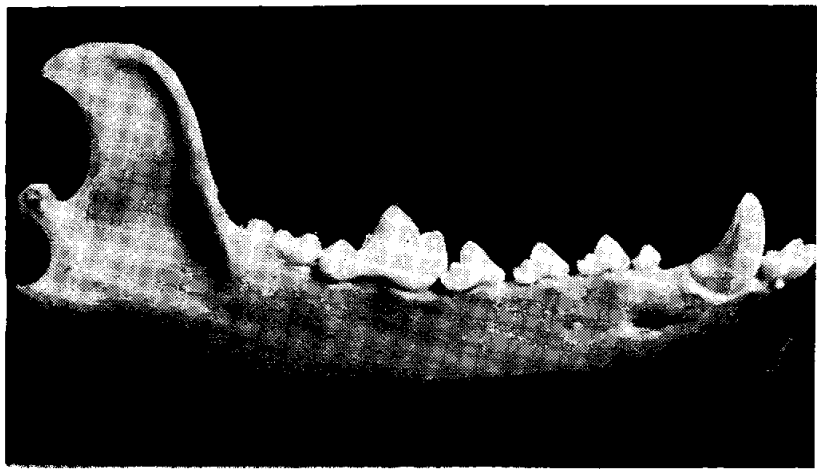

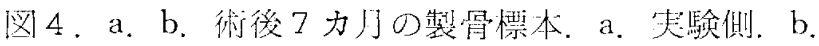
対照側

2) 計測所見

製骨標本を22項目の計測部位（方法参照）について, group 別に対照側亡実験側の平均值，变量狏散を算洁し te.

実験材料が小数例かつ雑種犬であるため，計測值に大 きなばらつきが考えられるので予め左右両群に打ける変 量分散を検し，その差が同一母集団からとった 2 groups が示す差の程度以内であるか否かを F-test を用い, $\mathrm{F}$ 一表 (分布) により判定した。標本分散が $\mathrm{F}$ 一值の有 意水準 $5 \%$ 以内にあるか否加を $\mathrm{F}=\mathrm{u}^{2} / \mathrm{v}^{2}$ により判定し た. (但 $\left.\iota^{2}>\mathrm{v}^{2}\right)$

その結果，標本分散が $\mathrm{F}$-值の有意水準 $5 \%$ 以内に含 まれるものがほとんどで, group 3. のif-goc, cd- 
gov, group 5. cd-gov, 関節頭傾斜出, group 6 . のcd-gov, $\mathrm{cl}-\mathrm{cl}^{\prime}$ の 6 項目が含まれなかった。 分散 が有意に異なっている事が確かめられたすのについて は，左右両群の平均值の差の有意性につき検討した．平 均値の差の有意性の検定には $\mathrm{t}$ 一分布により行なった。

$$
\begin{aligned}
& t_{0}=\frac{\overline{\mathrm{X}}-\overline{\mathrm{Y}}}{\omega} \sqrt{\frac{\overline{\mathrm{N}_{1} \mathrm{~N}_{2}}}{\mathrm{~N}_{1}+\mathrm{N}_{2}}} \quad \frac{\overline{\mathrm{X}}=\text { 左側の平均值 }}{\overline{\mathrm{Y}}=\text { 右側の平均值 }} \\
& \mathrm{N}_{1}=\text { 左側の実験数 } \\
& \mathrm{N}_{2}=\text { 右側の実験数 }
\end{aligned}
$$

この式により算出された $\mathrm{t}$ について, 左右両群の平 均值の差の有意性を判定する基準としては，危験率 $5 \%$ 扣よび10\%が使わ扎た。そして，てれを+の記号であら わした，すなわち，井は 5 \%で有意差汃認められ，十は 10\%で有意差がそれぞれ認められた事を示している.

上記の検定法は，標本分散が $\mathrm{F}$ 一值の有意水準 $5 \%$ 以 内にある場合であり，標本分散が $\mathrm{F}$ 一值の有意水準 $5 \%$
以外にある場合には次の式により判定した.

$$
t_{\mathrm{O}}=\frac{\overline{\mathrm{X}}-\overline{\mathrm{Y}}}{\mathrm{Sd}}, t_{\mathrm{c}}=\frac{\mathrm{S}^{2} \overline{\mathrm{x}} \cdot \mathrm{t}_{\mathbf{1}}+\mathrm{S} \overline{\mathrm{Y}} \cdot \mathrm{t}_{\mathbf{2}}}{\mathrm{S}^{2} \mathrm{~d}}
$$

$|t o|>t \mathrm{c}$ であれば, 左右側の平均值の差は $5 \%$ の危 険率で有意義であると判定した23,34).

各計測部位について，左側すなわち実験側が対照側に 比し差が認められるか否か，また各 groups の間には， どのような変化傾向が見られるかを, 左右側の平均值 との差の有意性について検討した。そ結果を表 3-1 （group 1.）〜表 3-7.（group 7.）に示した.

各計測項目に従って各 groups ごとの差および経時的 変化を見るに,

下顎骨の前後的発育についての計測 項目は, if $-\mathrm{cl}$, if $-\mathrm{cd}$, if $-\mathrm{cm}$, if-goc, if-crc, if-crd $66 つ$ る.

if $-\mathrm{cl}$ 各 groups とも実験側は対照側に比し発育が悪 く距離の減少傾向がみられ，その差が最高0.532cm〜最

表 3 Group I〜 7 の各群に関する実験側, 対照側の平均值, 分散, 差の検定

\begin{tabular}{|c|c|c|c|c|c|c|c|c|c|}
\hline \multicolumn{4}{|c|}{ L （実験側） } & \multicolumn{3}{|c|}{$\mathrm{R} \quad$ （対照側） } & \multicolumn{3}{|c|}{$\mathrm{L}-\mathrm{R}$} \\
\hline 計測部位 & $\mathrm{N}_{1}$ & $\overline{\mathrm{X}}$ & $S 2 \bar{x}$ & $\left|\mathrm{~N}_{2}\right|$ & $\overline{\mathrm{Y}}$ & $\mathrm{S}^{2} \overline{\mathrm{Y}}$ & $\mathrm{n}$ & $\mathrm{d}$ & to \\
\hline if $-\mathrm{cl}$ & 5 & 8.0220 & 0.4884 & 5 & 8.1040 & 0.471 .9 & 8 & -0.0820 & 0.1872 \\
\hline if $-c d$ & 5 & 8.0080 & 0.5492 & 5 & 8.0660 & 0.4911 & 8 & -0.0020 & 0.0040 \\
\hline if $-\mathrm{cm}$ & 5 & 7.8060 & 0.441 .8 & 5 & 7.8680 & 0.4223 & 8 & -0.0620 & 0.1 .489 \\
\hline if - goc & 5 & 7.8120 & 0.5043 & 5 & 8.0700 & 0.5127 & 8 & -0.1580 & 0.3484 \\
\hline if - crc & 5 & 7.7380 & 0.3371 & 4 & 7. 7030 & 0.2921 & 7 & +0.0350 & 0.0926 \\
\hline if - crd & 5 & 7. 4460 & 0.31 .93 & 5 & 7.4600 & 0.2597 & 8 & -0.0140 & 0.0409 \\
\hline $\mathrm{cd}-\mathrm{crd}$ & 5 & 1.3620 & 0.0394 & 5 & 1.. 4000 & 0.0427 & 8 & -0.0380 & 0.3005 \\
\hline crd - gov & 5 & 2. $49 \div 0$ & 0.0795 & 5 & 2.6240 & 0.1529 & 8 & -0.1320 & 0.6138 \\
\hline $\mathrm{cl}-\mathrm{gov}$ & 5 & 1.. 5560 & 0.0596 & 5 & J. 6260 & 0.0589 & 8 & -0.0700 & 0.4613 \\
\hline cd - gov & 5 & 1.6040 & 0.0580 & 5 & 1.6240 & 0.0648 & 8 & -0.0200 & 0.1264 \\
\hline $\mathrm{cm}-\mathrm{gov}$ & 5 & 1.1660 & 0.0239 & 4 & 1. 2830 & 0.0627 & 7 & -0.1770 & 0.8715 \\
\hline $\mathrm{cm}-\mathrm{cl}$ & 5 & 1.3180 & 0.0471 & 5 & 1.3900 & 0.0364 & 8 & -0.0720 & 0.5690 \\
\hline $\mathrm{cl}-\mathrm{cl}^{\prime}$ & 5 & 2.0300 & 0.2149 & 5 & 2.0480 & 0.1 .659 & 8 & -0.0080 & 0.0289 \\
\hline$\overline{\mathrm{ap}}_{2}-\overline{\mathrm{a}}_{\overline{\mathrm{p}} \boldsymbol{2}}$ & 5 & 1.2200 & 0.0098 & 5 & 1.2200 & 0.0099 & 8 & 0 & 0 \\
\hline aps $-a^{\prime} p_{3}$ & 5 & ]. 2400 & 0.0035 & 5 & 1. 3020 & 0.0036 & 8 & -0.0620 & 0.1633 \\
\hline $\begin{array}{l}a_{4}-a^{\prime} \bar{p}_{4} \\
a \bar{M}_{1}-a^{\prime} \bar{M}_{1} \\
a \bar{M}_{2}-a^{\prime} \bar{M}_{2}\end{array}$ & 5 & 1.3600 & 0.0109 & 5 & J. 3860 & 0.0115 & 8 & -0.0200 & 0.298 \\
\hline Angle of C. P. & 5 & 3.1 .1 .8500 & 13.1 .800 & 5 & 108.9500 & 8.61 .00 & 8 & +2.9000 & 1.3894 \\
\hline Angle of M. B. & 5 & $1.4] .0500$ & 27.07 .25 & 5 & 144.4000 & 1.4 .1 .750 & 8 & -3.3500 & 1.1 .667 \\
\hline Height of I. M. & 5 & 4.01 .00 & 0.3440 & 5 & 3.6200 & 0.2670 & 8 & +0.3900 & +4.7431 \\
\hline Inclin. of $\mathrm{C} . \mathrm{P}$. & 5 & 85.0500 & 1.6 .01 .25 & 5 & 87.7500 & 20.6875 & 8 & -2.7000 & 1.0237 \\
\hline
\end{tabular}

表 $3-1$

$\mathrm{Gr}$ o u p I の 計 測 值 (単位 $: \mathrm{cm}$ )

C. P. : Coronoid process

M. B. : Mandibular body
C. P. : Condyloid process

I. M. : Incisal margin 
表 $3-2$

G r o u p 2 の計测 值

(単位 $: \mathrm{cm}$ )

\begin{tabular}{|c|c|c|c|c|c|c|c|c|c|}
\hline \multicolumn{4}{|c|}{ L （実験側） } & \multicolumn{3}{|c|}{$R$ （刘照側） } & \multicolumn{3}{|c|}{$\mathrm{L}-\mathrm{R}$} \\
\hline 計測部位 & $\mathrm{N}_{1}$ & $\bar{X}$ & $\mathrm{~S}^{2} \overline{\mathrm{x}}$ & $\mathrm{N}_{2}$ & $\overline{\mathrm{Y}}$ & $\mathrm{S} 2 \bar{y}$ & $\mathrm{n}$ & d & $t_{0}$ \\
\hline if - cl & 5 & 8.9220 & 0.9822 & 5 & 9. 1680 & 1. 1536 & 8 & -0.0760 & 0.1167 \\
\hline if - cd & 5 & 8.6080 & 1.8425 & 5 & 9. 1.340 & 1. 1396 & 8 & -0.5260 & 0.6817 \\
\hline if $-\mathrm{cm}$ & 5 & 8. 7020 & $0.97 \subseteq 0$ & 5 & 8.8380 & 0.9670 & 8 & -0.1360 & 0.2180 \\
\hline if - goc & 5 & 8. 1830 & 1.51 .25 & 5 & 9.1500 & l. $14: 31$ & 8 & -0.9670 & 1.3295 \\
\hline if - crc & 5 & 8.9000 & J. 2674 & 5 & 9.0280 & 1. 3242 & 8 & -0.1280 & 0.01 .78 \\
\hline if - crd & 5 & 8.4620 & 1. 1.668 & 5 & 8.6380 & 1. 4949 & 8 & -0.1760 & 0.2359 \\
\hline $\mathrm{cd}-\mathrm{crd}$ & 5 & 1.5780 & 0.0333 & 5 & 1.6040 & 0.0331 & 8 & -0.0260 & 0.2283 \\
\hline crd - gov & 5 & 3.2120 & 0. 1.476 & 5 & 3.2800 & 0.1388 & 8 & -0.0680 & 0.2829 \\
\hline $\mathrm{cl}-\mathrm{gov}$ & 5 & 1. 7100 & 0.0569 & 5 & ]. 7440 & 0.1011 & 8 & -0.0340 & 0.1921 \\
\hline$c d-g o v$ & 5 & 1.5360 & 0.0538 & 5 & 1.7380 & 0.0289 & 8 & -0.2020 & 1.5970 \\
\hline $\mathrm{cm}-\mathrm{gov}$ & 5 & 1. 1520 & 0.1993 & 5 & 1.. 4200 & 0.0273 & 8 & -0.2880 & 1. 2462 \\
\hline $\mathrm{cm}-\mathrm{cl}$ & 5 & .1 .4320 & 0.0606 & 5 & 1. 5640 & 0.0598 & 8 & -0.1320 & 0.8348 \\
\hline $\mathrm{cl}-\mathrm{cl}^{\prime}$ & 5 & 1.9760 & 0.0562 & 5 & 2.1620 & 0.0892 & 8 & -0.1800 & 1.2203 \\
\hline$\overline{\mathrm{ap}_{2}}-\mathrm{a}^{\prime} \overline{\mathrm{p}_{2}}$ & 5 & 1.4640 & 0.0729 & 5 & 1. 4640 & 0.0631 & 8 & 0 & 0 \\
\hline$\overline{a_{1}}-a^{\prime} \bar{p}_{3}$ & 5 & 1.5320 & 0.0463 & 5 & ].. 5400 & 0.0516 & 8 & -0.0080 & 0.0563 \\
\hline$\overline{a p}_{4}-a^{\prime} \widetilde{p}_{4}$ & 5 & 1. 5940 & 0.0317 & 5 & 1.5860 & 0.0223 & 8 & +0.0080 & 0.0764 \\
\hline $\begin{array}{l}\mathrm{aM}_{1}-\mathrm{a}^{\prime} \overline{\mathrm{M}}_{1} \\
\mathrm{a} \overline{\mathrm{M}}_{2}-\mathrm{a}^{\prime} \overline{\mathrm{M}}_{2}\end{array}$ & 5 & 1.7800 & 0.0181 & 5 & 1.71 .60 & 0.0111 & 8 & +0.0620 & 0.7538 \\
\hline Angle of C.P & 5 & 1.17 .4500 & 26.8300 & 5 & 173.8000 & 41.9300 & 8 & +3.6300 & 0.9848 \\
\hline Angle of M. B. & 5 & 1.35 .3500 & 14.9875 & 5 & 145.9000 & 51.4250 & 8 & -10.5300 & ++2.8909 \\
\hline Height of I. M. & 5 & 5.0500 & 0.2050 & 5 & 4.0200 & 0. 1.1 .60 & 8 & +1.0300 & +1.4 .0713 \\
\hline Inclin. of C.P. & 5 & 81.4500 & 9.7625 & 5 & 87.7000 & נ.7313 & 8 & -6.2500 & || 3.0794 \\
\hline
\end{tabular}

低0.076 cmであり，著明な差は認められない，

if $-\mathrm{cd}$, if $-\mathrm{cm}$ 各 groups 已屯隇少傾向を示し有意 差は認められなかった。

if -goc 肉眼的所見であ述べたごとく，実験側の 角突起はかなり発育異常を示すすのであるから，それだ け，計測的にも変化が見られる。 各 groups 上も距離の 短縮を示し，実験側が対照側に比し最高 1. J.47cmから最 低0.158cmの差がみられる。group7。は $5 \%$ 危険率にて 有意差が認められ，group 4.では $1.0 \%$ 危険率で有意差 が認められる。

ifーcre 左右両側間の差が group 1. を除いた他の groups に扔いては, 滅少傾向すなわち，実験側が対照 側に比し距離の短縮がみられるが，著明な差は認められ ない.

if－crd 各 groups 亡あ対照側より距離の短縮を呈し ているが. 左右側の有意差は認められない.

筋突起の上下的発育すなわち, 高さを示す計測項目は cd-crd, crd-gov, の2つである.

cd-crd は関節頭からの高さであり, crd-gov は角
突起からの高さである.

cd-crd すべての groups に扔いて 刘照側より距離 の減少をみるが，ほ上んど有意的変化はない。

crd-gov 各 groups と屯対照側より距離の減少を示 している. 左右側の差は, 最高 $0.59 \mathrm{~cm}$ から最低 0.132 cmである. 5\%危険率では, group 4. 6. 7. に有意差 がみられ，10\%危険率では，group 3. 5. にそれぞれ認 められる。

関節突起の高さを表わす項目は, cl-gov, cd-gov, $\mathrm{cm}$-gov，の3つで，いずれす角突起からの距離であ る.

cl-gov すべての groups において, 対照側に比し 距離の減少傾向を示し, とくに group 3. に扔いては, 5\%の危険率で有意差がみられ，group 4.6. 亿ても $1.0 \%$ 危倹率で有意差が認められる。

cd-gov 各 groups と屯対照侧に比し距離の短縮を み, group 3.4. にては著明なる差が認められた。しか し，その差は経月的減少していく傾向を示している.

$\mathrm{cm}-$ gov 各 groups と无対照側に比し距離の短縮を 
表 $3-3$

G r o u p 3 の 計 測 值

(単位 $: \mathrm{cm}$ )

\begin{tabular}{|c|c|c|c|c|c|c|c|c|c|}
\hline \multicolumn{4}{|c|}{$\mathrm{L}$} & \multicolumn{3}{|c|}{$\mathrm{R}$} & \multicolumn{3}{|c|}{$L-R$} \\
\hline 計測部位 & $\mathrm{N}_{1}$ & $\bar{X}$ & $\mathrm{~S}^{2} \overline{\mathrm{x}}$ & $\left|\mathrm{N}_{2}\right|$ & $\overline{\mathrm{Y}}$ & $\mathrm{S}^{2} \overline{\mathrm{Y}}$ & $\mathrm{n}$ & $d$ & $t_{0}$ \\
\hline if $-\mathrm{cl}$ & 5 & $9.67 € 0$ & 0.5496 & 5 & 10.0140 & 0.6697 & 8 & -0.3380 & 0.6843 \\
\hline if $-\mathrm{cd}$ & 5 & 9.6100 & 0.5760 & 5 & 9.8880 & 0.6949 & 8 & -0.2780 & 0.5514 \\
\hline if $-\mathrm{cm}$ & 5 & 9.51 .80 & 0.6026 & 5 & 9.6260 & 0.6866 & 8 & -0.1080 & 0,2127 \\
\hline if - goc & 5 & $9.0860^{\circ}$ & 0.1038 & 5 & 10.0020 & 0.6707 & 8 & -0.9160 & $(-)$ \\
\hline if - crc & 5 & 9.8000 & 0.6417 & 5 & 10.0120 & 0.7536 & 8 & -0.2100 & $\quad 0.3975$ \\
\hline if - crd & 5 & 9.2400 & 0.4352 & 5 & 9.7220 & 1.3378 & 8 & -0.4820 & 0.8107 \\
\hline $\mathrm{cd}-\mathrm{crd}$ & 5 & 1.7980 & 0.0755 & 5 & 1.8240 & 0.0464 & 8 & -0.0260 & $\therefore \quad 0.1644$ \\
\hline crd - gov & 5 & 3. 2480 & 0. 885 & 5 & 3.6680 & 0.1591 & 8 & -0.4200 & +1.8974 \\
\hline $\mathrm{cl}-\mathrm{gov}$ & 5 & 1.5080 & 0.0504 & 5 & 1.8500 & 0.0317 & 8 & -0.3420 & +2.5748 \\
\hline$c d-g o v$ & 5 & 1.5300 & 0.0068 & 5 & 1. 9160 & 0.0587 & 8 & -0.3860 & $\cdot(t)$ \\
\hline $\mathrm{cm}-\mathrm{gov}$ & 5 & 1.0820 & 0.0180 & 5 & 1.6000 & 0.0429 & 8 & -0.5180 & +4.5500 \\
\hline $\mathrm{cm}-\mathrm{cl}$ & 5 & 1.3980 & $0.02 \mathrm{~J} .2$ & 5 & 1. 5900 & 0.0303 & 8 & -0.1 .920 & +1.8975 \\
\hline $\mathrm{cl}-\mathrm{cl}^{\prime}$ & 5 & 2.0480 & 0.0837 & 5 & 2. 1.780 & 0.1036 & 8 & -0.1300 & 0.6716 \\
\hline$\overline{\mathrm{ap}_{2}}-\mathrm{a}_{\overline{\mathrm{p}_{2}}}^{\overline{n^{2}}}$ & 5 & 1.3940 & 0.0385 & 5 & 1.4200 & 0.0392 & 8 & -0.0260 & 0.2087 \\
\hline$\overline{a p s}-a_{\overline{p s}}$ & 5 & 1.3600 & 0.0334 & 5 & 1.4200 & 0.0683 & 8 & -0.0600 & 0.4218 \\
\hline$\overline{a p_{4}}-a^{\prime} p_{4}$ & 5 & 1. 4320 & 0.0443 & 5 & 1.. 4640 & 0.0626 & 8 & -0.0320 & 0.2181 \\
\hline $\mathrm{a} \overline{\mathrm{M}}_{1}-\mathrm{a}^{\prime} \overline{\mathrm{M}}_{1}$ & 5 & 1.5540 & 0.0350 & 5 & 1.4680. & 0.0207 & 8 & +0.0860 & 0.8000 \\
\hline $\mathrm{a} \overline{\mathrm{M}}_{2}-\mathrm{a}^{\prime} \overline{\mathrm{M}}_{2}$ & 4 & 1. 4975 & 0.0239 & 4 & 1.3375 & 0.0242 & 6 & +0.1600 & 0. $f(222$ \\
\hline Angle of C. P. & 5 & 1.15 .0000 & $40.62 \mathrm{CO}$ & 5 & 108.5000 & 27.0000 & 8 & +6.5000 & $=1.7658$ \\
\hline Angle of $\mathrm{M} . \mathrm{B}$. & 5 & 1.33 .4000 & 18.925 & 5 & 152.5000 & 29.2500 & 8 & -19.1000 & +46.1505 \\
\hline Height of I. M. & 5 & 5.6600 & 0.4690 & 5 & 3.7600 & 0.2493 & 8 & +1.900 & H5.0068 \\
\hline Inclin. of C. P. & 5 & 83. 9000 & 7.7688 & 5 & so, 1.1.100 & 9.7420 & 8 & -6.2100 & +3. 3171 \\
\hline
\end{tabular}

み, group 3. から group 6. Kかりて有意差がみら れ，とくに group 3.4. 亿おいては著明な差が認めら れる，group 7. に括いても1.0\%危険率で有意差があ

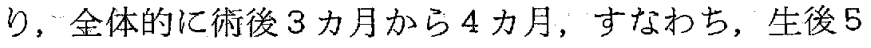
カ月から6力月にかけ著明な差が生じている，左右側の 差の変化傾向は波状を呈しその傾向は定っていない。

$\mathrm{cm}-\mathrm{cl}$ 関節頭の長径を表放し，各 groups と6距離 の減少を示している. group 3，5，6，7，では， 10\%危険率でそれぞれ有意差が認められる。

$\mathrm{cl}-\mathrm{cl}^{\prime}$ 筋突起の前後径を表わす項目である，各 groups のいずれむ対照側に比し 距離の減少がみられ る.

下顎体の高さを表わす項目は， $\quad \mathrm{aP}_{\mathbf{2}}-\mathrm{a}^{\prime} \overline{\mathrm{P}_{2}}, \quad \mathrm{a} \overline{\mathrm{P}_{3}}-$ $\mathrm{a}^{\prime} \overline{\mathrm{P}_{3}}, \quad \mathrm{a} \overline{\mathrm{P}_{4}}-\mathrm{a}^{\overline{\mathrm{P}_{4}}}$ の小画部之, $\quad \mathrm{a \overline {M } _ { 1 }}-\mathrm{a}^{\prime} \overline{\mathrm{M}}_{1}, \quad \mathrm{a} \overline{\mathrm{M}}_{\mathbf{2}}-$ $\mathrm{a}^{\prime} \mathbf{M}_{2}$ の大臼歯部である。

$\overrightarrow{\mathrm{a}} \overline{\mathrm{P}_{2}}-\mathrm{a}^{\prime} \overline{\mathrm{P}_{2}}$ group 1.2. に抬いては各 groups 屯, 対照側に比し距離の減少傾向がみられるが, 各 groups 著明な差は認められない. $\mathrm{a} \overline{\mathrm{P}}_{3}-\mathrm{a}^{\overline{\mathrm{P}}} \overline{\mathrm{P}}_{3}$ すべての groups ¿文対照惻に比し距離 の減少を生ずるが，計測項目 $\mathrm{a} \overline{\mathrm{P}_{2}}-\mathrm{a}^{\overline{\mathrm{P}}} \overline{2}_{2}$ 同様 著明な差 は䛑められない。

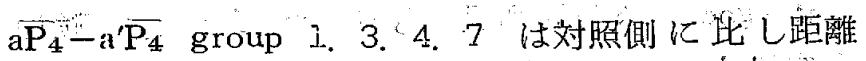
の減少をみ, group 2.5.6 に括いては逆に増加の傾 向を示す。各 groups と屯著明な差は認められない

$\mathrm{a} \overline{\mathrm{M}}_{1}-\mathrm{a}^{\prime} \overline{\mathrm{M}}_{1}$ groupl.では未萠出のため計測できなか った. group 2. を除いた他の groups は，対照側陌比 し距離の增加がみられたが，上くに，group，7，では， その傾向が強く有意差を認好る。

$\mathrm{a}_{2}-\mathrm{a}^{\prime} \overline{\mathrm{M}}_{2}$ group 1.2. 2. 飞求いてい；前記同様来萠 出のため計測できなかったが, group 3. がら group\%。

にいたり距離の増加を示しているが．著明な差は認めら れない。

以上の結果により，小曰歯部は対照側に比し距離の減 少, 大曰歯部では逆に増加が認められる。

筋突起角 各 groups : も対照側に比し角度の掘大办 見られ，とくに group 7. では5\%危険率で，また 
表 $3-4$

$\mathrm{Gr} \circ \mathrm{u} \mathrm{p} 4$ の計測 值

(単位 $: \mathrm{cm}$ )

\begin{tabular}{|c|c|c|c|c|c|c|c|c|c|}
\hline \multicolumn{4}{|c|}{$\mathrm{L}$} & \multicolumn{3}{|c|}{$\mathrm{R}$} & \multicolumn{3}{|c|}{$\mathrm{L}-\mathrm{R}$} \\
\hline 計測部位 & $\mathrm{N}_{1}$ & $\bar{X}$ & $\mathrm{~S}^{2} \overline{\mathrm{x}}$ & $\mathrm{N}_{2}$ & $\overline{\mathrm{Y}}$ & $S^{2} \bar{x}$ & $\mathrm{n}$ & $\mathrm{d}$ & $t_{\mathrm{o}}$ \\
\hline if $-\mathrm{cl}$ & 5 & 9.2140 & 0.3344 & 5 & 9.7460 & 0.6335 & 8 & -0.5320 & 1. 2085 \\
\hline if - cd & 5 & 9.1840 & 0.4450 & 5 & 9.6640 & 0.5653 & 8 & -0.4800 & 1.0674 \\
\hline if $-\mathrm{cm}$ & 5 & 9.21 .27 & 0.4405 & 5 & 9.3600 & 0.4967 & 8 & -0.1480 & 0.3421 \\
\hline if - goc & 5 & 8.7000 & 0.4815 & 5 & 9.7380 & 0.7349 & 8 & -1.0380 & $+1+2.1041$ \\
\hline if - crc & 5 & 9.3860 & 0.5415 & 5 & 9.7440 & 0.5994 & 8 & -0.3580 & 0.7525 \\
\hline if - crd & 5 & 8.9980 & 0.3523 & 5 & 9.1 .720 & 0.7679 & 8 & -0.1740 & 0.3668 \\
\hline$c d-c r d$ & 5 & 1.6880 & 0.031 .3 & 5 & 1.8620 & 0.0439 & 8 & -0.1 .740 & 1. 4478 \\
\hline crd - gov & 5 & 3. 1840 & 0.0993 & 5 & 3.6560 & 0.0855 & 8 & -0.4720 & +2.4876 \\
\hline $\mathrm{cl}-$ gov & 5 & 1.6320 & 0.0607 & 5 & 1. 9080 & 0.0128 & 8 & -0.2760 & +2.2968 \\
\hline cd - gov & 5 & 1.5280 & 0.0503 & 5 & 1. 9420 & 0.0238 & 8 & -0.4140 & +3. 4453 \\
\hline $\mathrm{cm}-\mathrm{gov}$ & 5 & 1.0740 & 0.0206 & 5 & 1. 5940 & 0.0376 & 8 & -0.5200 & $H 4.8364$ \\
\hline $\mathrm{cm}-\mathrm{cl}$ & 5 & 1. 4420 & 0.0539 & 5 & 1.6260 & 0.0569 & 8 & -0.1840 & 1.2121 \\
\hline $\mathrm{cl}-\mathrm{cl}^{\prime}$ & 5 & 1.9380 & 0.0692 & 5 & 2. 1720 & 0.1733 & 8 & -0.2340 & 1.0632 \\
\hline $\mathrm{ap}_{2}-\mathrm{a}^{\prime} \mathrm{p}_{2}$ & 5 & 1. 2720 & 0.0217 & 5 & 1.3120 & 0.0139 & 8 & -0.0400 & 0.4716 \\
\hline$\overline{\mathrm{ap3}}-\mathrm{a}^{\prime} \mathrm{p}_{3}$ & 5 & 1.2120 & 0.0233 & 5 & 1. 2300 & 0.031 .7 & 8 & -0.0180 & 0.171 .7 \\
\hline$\overline{a p_{4}}-a^{\prime} p_{4}$ & 5 & 1.3240 & 0.0379 & 5 & 1. 3520 & 0.0454 & 8 & -0.0280 & $0.21: 72$ \\
\hline $\mathrm{a} \overline{\mathrm{M}}_{1}-\mathrm{a}^{\prime} \overline{\mathrm{M}}_{1}$ & 5 & 1.5260 & 0.0534 & 5 & 1.5020 & 0.0450 & 8 & +0.0860 & 1.2523 \\
\hline $\mathrm{a} \overline{\mathrm{M}}_{2}-\mathrm{a}^{\prime} \overline{\mathrm{M}}_{2}$ & 5 & 1.6620 & 0.0492 & 5 & ]. 5300 & 0.0477 & 8 & +0.1320 & 1.3760 \\
\hline Angle of C. P. & 5 & 111.0000 & 43.9100 & 5 & 105.0000 & 16.0000 & 8 & +6.000 & 1.7343 \\
\hline Angle of $M . B$. & 5 & 131.3000 & 36.5750 & 5 & 147.3500 & 34.8666 & 8 & -16.0500 & +4.2438 \\
\hline Height of I. M. & 5 & 5. 7600 & 0.2293 & 5 & 4. 2300 & 0.2795 & 8 & +1.5300 & +14.7998 \\
\hline Inclin. of C.P. & 5 & 77.3600 & 63.3563 & 5 & 90.1000 & 20.1 .125 & 8 & -12.8000 & +3. 1.328 \\
\hline
\end{tabular}

group 6. ではJ.0\%危険率でそれぞれ有意差が認められ る.

下頡体角 各 groups 亡角度の狭少をみ，group 1. を除いたすべての groups は対照側に 比し著明な差 すなわち有意差が認められる。

切歯縁高 各 groups とあ対照側に比し著明な差がみ られ，group 5. は10\%危険率で，他の groups は group 5. を除き $5 \%$ 危険率でそれぞれ有意差が認めら れる。

関節頭傾斜角 各 groups ट市対照側に比し角度の狭少を み，下顎体角同様 group 1.を除いたすべての groups に著明な差が認められる。

主なる計測部位 8 項目に招ける左右側の差は, 表 (4) に示した.

\section{3） $\mathbf{X}$ 線的所見}

\section{Group 1.}

対照側 萠出歯は乳歯列であるが， $\mathrm{P}_{1}$ 歯胚は根形成 がかなり進行し，萠出閒近い状態にある， $M_{1}$ 歯肧は， いまだ曾冠形成から根形成の初期段階に移行している. $\mathrm{M}_{2}$ 歯胚はさらに幼若形にして歯冠の形成途上にあり,
$\mathrm{M}_{1}$ 歯怔とともに曾小囊を介しての周用骨柱は，白線と してみられる，また， $\mathrm{M}_{2}$ 歯肧の上部骨質はとくに緻察 にして不透過像を呈し，他の永久歯雪肧はそれぞれの先 行乳崡下に幼若型として存在している. 筋乫起の前縁お よび後縁部骨柱む密にして，前下方に走向をとってい る. 筋乫起の中軸部㧍よび咬筋窩辺の骨柱は網状配列を なし，関節突起拉よびその下縁部の骨柱はかなりの緻密 さを示すが，それらの配列方向は明らかでない，下顎骨 は，下顎孔より骨体下縁に沿って走行しているが $\mathrm{M}_{1}$ 歯 肧部ではその部の骨体高径の約 $1 / 7$ 程度の太さを示し， 犬歯菡根尖部にてその透過像を消失している，な㧍，下 顎管に下在する下顎枝下縁加ら骨休下縁にかけての骨柱 は著しく密である。

実験側 角突起が対照側に比し，発育が悪く，かつ骨 柱の配列がやや疎に見られる他，永久崡歯胚の発育状況 扔よびその他下顎枝各部の柱骨の構築状沉にはほとんど 差が認められない。

\section{Group 2.}

実験側の下顎枝各部にお汀る骨柱の緻密層は, 対照倒 に比してやや少なく，全般的に粗造な配列部が多い． 


\begin{tabular}{|c|c|c|c|c|c|c|c|c|c|}
\hline \multicolumn{4}{|c|}{$\mathrm{L}$} & \multicolumn{3}{|c|}{$\mathbf{R}$} & \multicolumn{3}{|c|}{$\mathrm{L}-\mathrm{R}$} \\
\hline 計测部位 & $\mathrm{N}_{1}$ & $\bar{X}$ & $\mathrm{~S} 2 \overline{\mathrm{x}}$ & $\left|\mathrm{N}_{2}\right|$ & $\overline{\mathrm{Y}}$ & $\mathrm{S}^{2} \overline{\mathrm{Y}}$ & $\mathrm{n}$ & $\mathrm{d}$ & to \\
\hline if $-\mathrm{cl}$ & 5 & 9.7620 & 0.2703 & 5 & 10.1 .840 & 0.2805 & 8 & -0.2240 & 1.2709 \\
\hline if - cd & 5 & 9.7600 & 0.3030 & 5 & 10.1200 & 0.3099 & 8 & -0.3600 & 1.0274 \\
\hline if $-\mathrm{cm}$ & 5 & 9.5840 & 0.2820 & 5 & 9.7080 & 0.2903 & 8 & -0.1240 & 0.3665 \\
\hline if - goc & 5 & 9.3980 & 0.6835 & 5 & 1.0 .1200 & 0.3030 & 8 & -0.7720 & 1.6262 \\
\hline$c f-c r c$ & 5 & 9.5280 & 0.2222 & 5 & 9.9160 & 0.3595 & 8 & -0.3880 & 1. 1373 \\
\hline if $-c r d$ & 5 & 9.0820 & 0.6278 & 5 & 9.5680 & 0.3529 & 8 & -0.4860 & 1.0977 \\
\hline$c d-c r d$ & 5 & 1.7900 & 0.0603 & 5 & 2.0160 & 0.0625 & 8 & -0.2260 & 1.6241 \\
\hline crd - gov & 5 & 3.2980 & 0.1337 & 5 & 3.71 .80 & 0.0530 & 8 & -0.4200 & +2.1422 \\
\hline $\mathrm{cl}$ - gov & 5 & $1 . .6360$ & 0.0778 & 5 & 1.8560 & 0.0199 & 8 & -0.2200 & 1.5809 \\
\hline$c d-g o v$ & 5 & 1.6960 & 0.2263 & 5 & 1.9180 & 0.0081 & 8 & -0.2220 & $(-)$ \\
\hline $\mathrm{cm}-\mathrm{gov}$ & 5 & ]. 3380 & 0.0469 & 5 & 1.6240 & 0.0163 & 8 & -0.2860 & \#2.51.22 \\
\hline $\mathrm{cm}-\mathrm{cl}$ & 5 & ]. 5240 & 0.0189 & 5 & 1.6780 & 0.0075 & 8 & -0.1540 & +2.0283 \\
\hline $\mathrm{cl}-\mathrm{cl}^{\prime}$ & 5 & 2.1380 & 0.0772 & 5 & 2.2660 & 0.0290 & 8 & -0.1280 & 0.8762 \\
\hline$\overline{a p_{2}}-a^{\prime} \bar{p}_{2}$ & 5 & 1.3380 & 0.0038 & 5 & 1.3800 & 0.0029 & 8 & -0.0420 & 1.. 0580 \\
\hline$a \overline{p_{3}}-a^{\prime} p_{s}$ & 5 & ]. 2760 & 0.0066 & 5 & 1.2960 & 0.0036 & 8 & -0.0200 & 0.1462 \\
\hline$\overline{a_{4}}-a^{\prime} p_{4}$ & 5 & 1.3960 & 0.0219 & 5 & 1.3920 & 0.0059 & 8 & +0.0040 & 0.0534 \\
\hline$a \bar{M}_{L}-a^{\prime} \overline{\mathbf{M}}_{1}$ & 5 & 1.5820 & 0.0116 & 5 & 1. 4960 & 0.01 .18 & 8 & +0.0860 & 1. 2523 \\
\hline $\mathrm{a} \overline{\mathrm{M}}_{2}-\mathrm{a}^{\prime} \overline{\mathrm{M}}_{2}$ & 5 & 1.. 6640 & 0.0073 & 5 & 1.5300 & 0.01 .76 & 8 & +0.1340 & 0.6002 \\
\hline Angle of C. P & 4 & 1.09 .3750 & 55.4800 & 4 & 1.04 .8130 & 10.0600 & 6 & +4.5700 & 1. 1.298 \\
\hline Angle of $\mathrm{M} . \mathrm{B}$. & 4 & $138.12 \Xi 0$ & 35.4500 & 4 & 149.6880 & 35.9073 & 6 & -11.5600 & H2.7338 \\
\hline Height of I. M. & 4 & 5.1000 & 0.1490 & 4 & 4.0880 & 0.4398 & 6 & +1.01 .00 & +2.281 .6 \\
\hline Inclin. of C.P. & 5 & 82.3000 & 32.9188 & 5 & 92.1000 & 2.3625 & 8 & -9.8000 & +3.1328 \\
\hline
\end{tabular}

実験側の角突起は, 著しい発育異常が見られる. 両側と も， $\overline{\mathrm{P}}_{1}$ が落出し， $\mathrm{M}_{1}$ もわずかに菌冠尖を萠出させてい る. $\mathrm{M}_{2}$ 歯肽は根形成が進行し，歯冠尖が骨上縁近くに 達している．M3 歯胚はまだ鐘状エナメル器にして，㐘 冠尖部の硬組織形成をはじめている程度である． P \&-4

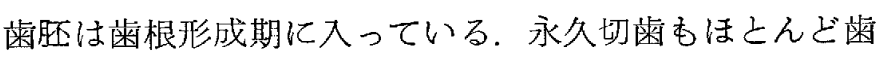
槽骨縁上に萌出しはじめているが残留乳畨が混在してい る. (図. 5. a. b.)

\section{Er sup 3.}

両侧之も，関節頭より関節突起棱に沿う骨柱がかなり 維密化している。その程度は，対照側より明白である。

下顎骨体下縁の緻密層は，厚味をまし，それに応じて下 歯槽管は上方に移行している，下顎孔は，対照側に比し て前方に位し， $\mathrm{M}_{3}$ 歯胚は下方にみられる。

雪列関係 両側上屯 $I_{1-3}, P_{1}, M_{1}$ は完全に萠出， $M_{2}$ はほとんど萠出しかけている，Cも一部萠出している が，その先行歯がまだ混在している，P 2-4 雬肧 の歯根 形成は，左右側いずれも平等に近い進行を示す。それら 先行歯の根尖にはすでに吸収像が見られる。 $\mathrm{M}$ は は歯冠

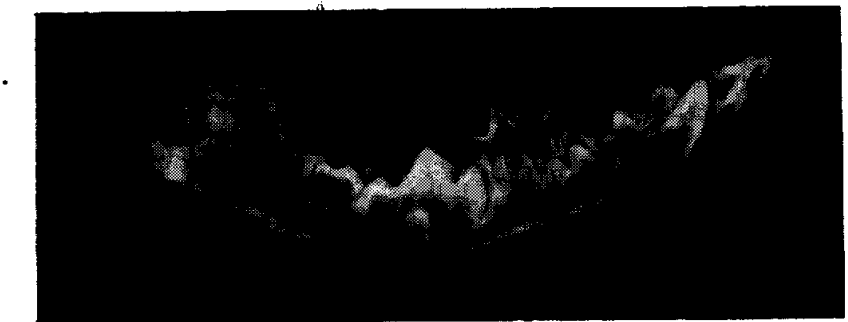

b.

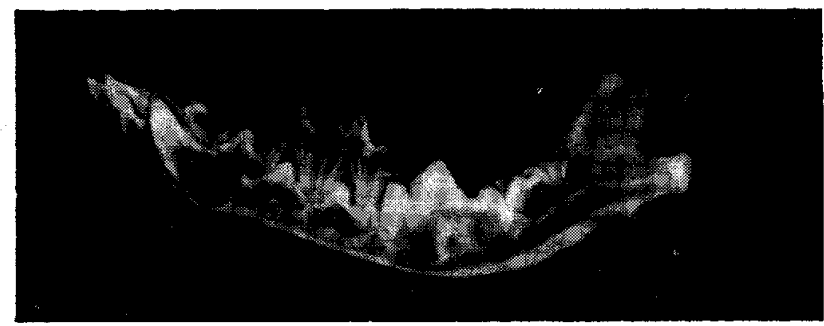

図5.a.b. 術後 2 ,力月のX線写真，a，実験側， b. 対照側.

形成から雷根形成に大っている.

\section{Group 4.}

本群においては，両側とも全永久歯が完全に萠出し， 所謂永久歯列を示している。実験側の咬筋窝部は，対照 


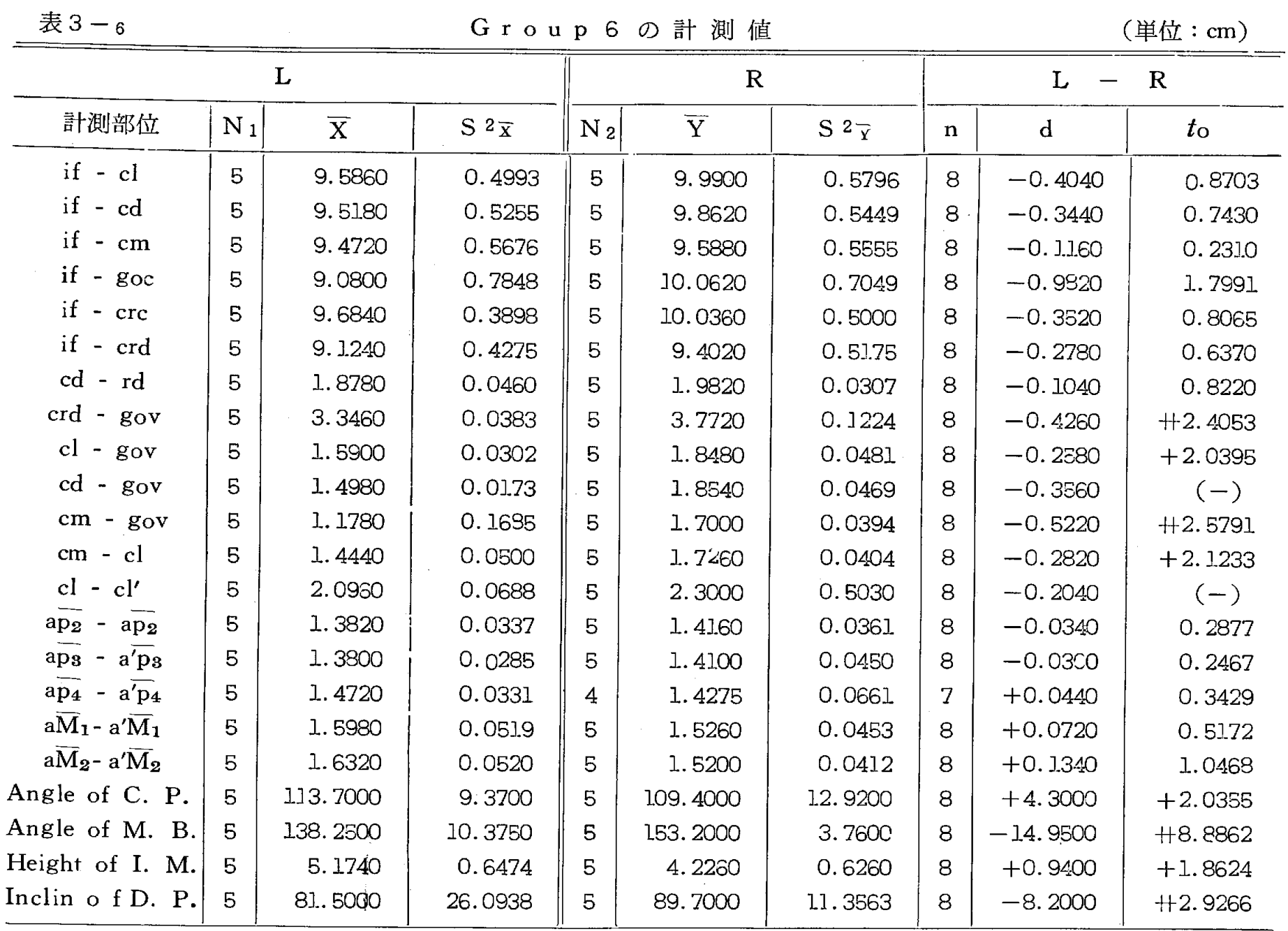

側に比して，わずかに不透過度をましている。また，実 験側M3 の筋突起前縁の周囲骨は，対照側に比して緻密 化が遅れ，透過度をましている。ささらに，実験側 $\mathrm{M}_{1}$ お よび $\mathrm{P}_{4}$ の槽内中隔部は, 対照側に比して透過度を増し ている.

\section{Group 5. $\sim 7$.}

成長にしたがい，下顎管厚径の増大が両側之も共通し ている. また，オトガイ孔も P 3 根尖下の骨柱中に明瞭 化している，下顎枝全体をみるに，前群に続いて実験側 の咬筇简，とくにその下方部と関節突起稜部の骨柱が複 雑に維密化し, 術後期間の長いあの程不規則な不透過度 をましている．雪列中, $\mathrm{P}_{2}$ 加ら $\mathrm{M}_{3}$ にかけての槽内中 隔骨柱も成長に応じて充実化し，そのほとんどが下䫑体 の前後方向に平行に配列している。しかし，両側とも， $\mathrm{P}_{4}\left\llcorner\mathrm{M}_{1}\right.$ の槽内中隔骨柱は, group 7, に至るも完全 充実化が進行せず，根端 $1 / 3$ 部の骨質はかなりの透過度 を示している。 その透過度は実験側においてやや強い。 なお， group 6. になると実験側毛 対照側同様， P 1
〜 P 8 歯列部は, 歯牙で相接触せず間隙を生じてくる.

(図 6. a. b.)

a.

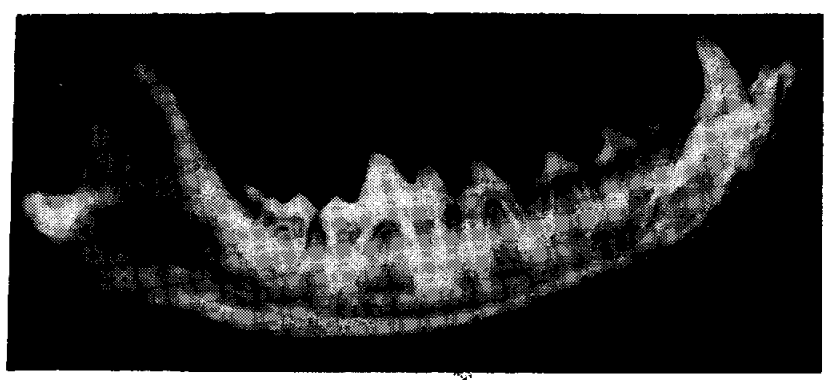

b.

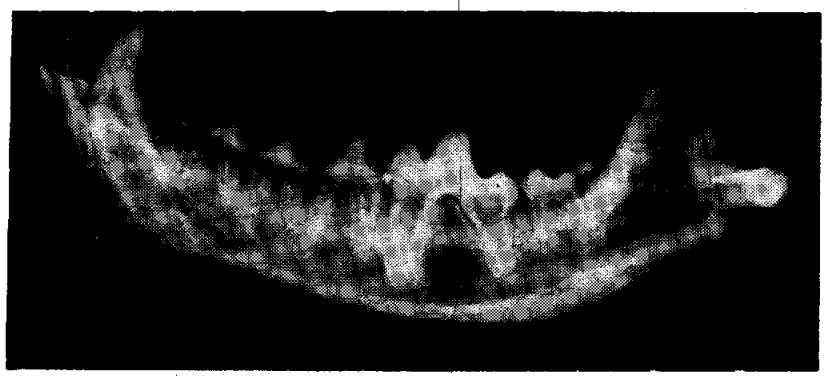

図6，a，b: 術後 6 力月のX線写真. a. 対嘿側，b. 奏験側! 
表 $3-7$

G r o u p 7 の 計 测 值

(単位 $: \mathrm{cm}$ )

\begin{tabular}{|c|c|c|c|c|c|c|c|c|c|}
\hline \multicolumn{4}{|c|}{$\mathrm{L}$} & \multicolumn{3}{|c|}{$\mathrm{R}$} & \multicolumn{3}{|c|}{$\mathrm{L}-\mathrm{R}$} \\
\hline 計湘部位 & $\mathrm{N}_{1}$ & $\overline{\mathrm{X}}$ & S $2 \bar{x}$ & $\mathrm{~N}_{2}$ & $\bar{Y}$ & $\mathrm{~S}^{2} \overline{\mathrm{Y}}$ & $\mathrm{n}$ & d & $t_{0}$ \\
\hline if $-\mathrm{cl}$ & 10 & 10.8410 & 1.0444 & 10 & 11.2160 & 1.2754 & 18 & -0.3750 & 0.1765 \\
\hline if - cd & 10 & 10.861 .0 & 1. 1496 & 10 & 11.1 .770 & 1.1048 & 18 & -0.3160 & 0.6483 \\
\hline if $-\mathrm{cm}$ & 10 & $-\quad 10.7220$ & 1.1610 & 10 & 10.8420 & 1. 1.809 & 18 & -0.1200 & 0.2484 \\
\hline if - goc & 10 & 10.1 .400 & 0.9849 & 10 & 11. 2890 & 1.1719 & 18 & -1.1470 & +2.4662 \\
\hline if - crc & 10 & 11.0150 & 1. 1045 & 10 & ].]. 3340 & 1. 244$]$ & 18 & -0.3190 & 0.6605 \\
\hline if - crd & 10 & 10.4850 & 0.9346 & 10 & 10.6570 & 1.0557 & 18 & -0.1720 & 0.3854 \\
\hline $\mathrm{cd}-\mathrm{crd}$ & 10 & 2.2140 & 0.1045 & 10 & 2.3820 & 0.0749 & 18 & -0.1680 & 1.2650 \\
\hline $\mathrm{crd}-\mathrm{gov}$ & 10 & 3. 7970 & 0.1 .941 & 10 & 4.3870 & 0.1 .11 .4 & 18 & -0.5900 & H3.0897 \\
\hline $\mathrm{cl}-\mathrm{gov}$ & 10 & 1.9840 & 0.3248 & 10 & 2.2680 & 0.1773 & 18 & -0.2840 & 1. 2677 \\
\hline $\mathrm{cd}-\mathrm{gov}$ & 3.0 & 2.0640 & 0.3574 & 10 & 2.2810 & 0.1502 & 18 & -0.2170 & 0.9627 \\
\hline $\mathrm{cm}-\mathrm{gov}$ & 10 & 1. 6240 & 0.2159 & 10 & 1. 9860 & 0.0921 & 18 & -0.3620 & H2.6598 \\
\hline $\mathrm{cm}-\mathrm{cl}$ & 10 & 1.7210 & 0.0676 & 10 & 1. 9610 & 0.0666 & .8 & -0.2400 & +2.0722 \\
\hline $\mathrm{cl}-\mathrm{cl}^{\prime}$ & 10 & 2.3490 & 0.2210 & 10 & 2.5530 & 0.2329 & 18 & -0.2040 & 0.9794 \\
\hline $\mathrm{a} \overline{\mathrm{p}_{2}}-\mathrm{a}^{\prime} \mathrm{p}_{2}$ & 10 & 1.5880 & 0.0766 & 10 & 1.6040 & 0.0559 & 18 & -0.1160 & 1.0054 \\
\hline$\overline{\mathrm{aps}}-\mathrm{a}^{\bar{t} \mathrm{p}_{3}}$ & 10 & 1.5450 & 0.0683 & 10 & 1.5830 & 0.0630 & 18 & -0.0390 & 0.3406 \\
\hline$\overline{a p_{4}}-a^{\prime} p_{4}$ & 10 & 1.6410 & 0.0372 & 10 & 1.6720 & 0.0304 & 18 & -0.031 .0 & 0.3766 \\
\hline $\mathrm{a}_{1}-\mathrm{a}^{\prime} \overline{\mathrm{M}}_{1}$ & 10 & 1.8980 & 0.0420 & 10 & 1.7910 & 0.0331 & 18 & +0.1070 & $(+)$ \\
\hline $\mathrm{a} \overline{\mathbf{M}}_{2}-\mathrm{a}^{\prime} \overline{\mathrm{M}}_{2}$ & 10 & 1.9400 & 0.0533 & 10 & 1.8280 & 0.0442 & 18 & +0.1160 & 1. 1738 \\
\hline Angle of $\mathrm{C} . \mathrm{P}$. & 8 & 114.6630 & 5.9500 & 8 & 109.9440 & 10.4500 & 14 & +4.7200 & \#3. 2892 \\
\hline Angle of $M . B$. & 8 & 135.6880 & 52.6879 & 8 & 152.4690 & 17.8390 & 14 & -16.7800 & +5. 6498 \\
\hline Height of I. M. & 8 & 6.2863 & 0.3692 & 8 & 4.3563 & 0.4511 & 14 & +1.9300 & H6.0124 \\
\hline Inclin. of C. P. & 7 & 80.5700 & 41.4598 & 7 & 90.7500 & 30.2188 & 12 & -10.1800 & +3.9026 \\
\hline
\end{tabular}

表 4

下顎骨成長に伴う主なる計測部位の左右側差（\%)

\begin{tabular}{|c|c|c|c|c|c|c|c|}
\hline $\begin{array}{c}\text { 期間(月) } \\
\text { 計測部位 }\end{array}$ & 1 & 2 & 3 & 4 & 5 & 6 & 7 \\
\hline if $-\mathrm{cl}$ & -0.51 & -0.42 & $3-1.72$ & -2.81 & -2.22 & -2.06 & -1.70 \\
\hline if - goc & -0.99 & -5.58 & -4.80 & -5.63 & -3.96 & -5.13 & -5.36 \\
\hline if - crc & +0.23 & -0.71 & -1.06 & -1.87 & -1.99 & -1.78 & -1.43 \\
\hline $\mathrm{cm}-\mathrm{gov}$ & -7.23 & -10.42 & -19.31 & -19.49 & -9.66 & -18.14 & -10.03 \\
\hline $\mathrm{a} \bar{M}_{1}-a^{\prime} \bar{M}_{1}$ & & -1.77 & +2.85 & +0.79 & +2.80 & +2.30 & +2.09 \\
\hline Angle of M. B. & -1.1 .7 & -3.75 & -6.68 & -5.76 & -4.02 & -5.13 & -5.82 \\
\hline Height of I. M. & +5.1 .1 & +11.36 & +20.17 & +15.32 & +1.1 .97 & +10.00 & +18.13 \\
\hline Inclin. of C. P. & -1.56 & -3.70 & -3.57 & -7.65 & -5.72 & -4.79 & -5.94 \\
\hline
\end{tabular}

\section{4）分裂線法的所見}

従来 Beffringhoff（1925） とその一門纯より線維構 築の研究が技されているが，てれらはその線系のみに触 れているのに対して，中山25广は不整裂線 の存在を強調 し，それが発育方向の乱れであって，生理的機能その他 の外力的影響付する骨質自身の防禦反応としての直接 的機能表現であり, 不整裂線団之線系の消長が骨発育様
相を示す発青過程図であると主張している。 この見解に 基いて肉眼的，計測的，およびX線所見との関連を見る ため，前記所見に見られる形態的変化を生じた下顎骨老 とくに下顎枝部を中心に経月的に実験側㧍よび対照側の 内外両面における分裂線の変化状況を観察した。

\section{実験 側}

Group 1.（生後 3力月） 


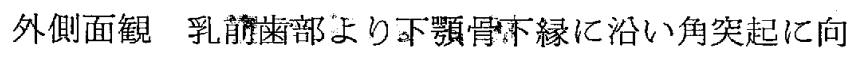
う横走め平行線系 (1) 飞よって充されているが，角突 起部にわず办線系の乱机（2）が認められる。 また， 下顎枝に胁いては，筋突起上部に 2 〜 条の斜走線 系 (3.)を認めるのみで，他の部は不整裂線団（4）によ って充されている。（図 7. a.)

内側面観: 外側観とほぼ同様であるが，下蕦枝中央部 における不整裂線団（4）は，外側面に比してその範囲 は著しく狭く筋突起後縁部に和ずか代認多られるのみで ある。（図 7。b.)

Group 2. (生後 4 力神)

外側面観 group I. での角乫起部㧍よび下頕枝部に 見られた不整裂線（2），(4) は，之の領域を前後抢よ び正下の方向作大している。（図 8：a.)

：内側面観 group 1. 上活活同様の所見を示している 祘不整裂線団（4）は，grøup 1. 亿比して，之の領域 が前方に広がっている。（図8，b.)

\section{Group 3: (生後5为月)}

外側面観”“角突起部の不整裂線団(20は，市顎下縁 位沿さてさらに前方伦海の領域を広めている。また，下

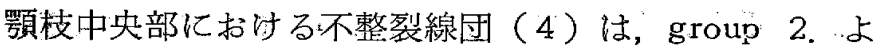

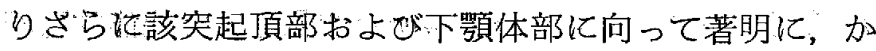

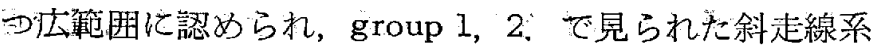

(3) は全く消失している。（図 9,a.)

内側面観 group 2：で前方中央部に拡大した不整裂 線団（4）は，さらに前方および上方比とその領域を広 め, 斜走線系 (3) は該突起前縁に沿う部に認められる のみである。（图 9.bi)

Group 4. (生後6力月)

外側面観 group 3. で見られた角突起部の不整裂線 団（2）は，前上方にその領域を広め，不整裂線団（4 ），之合して広範围に出現している。しかし，筋突起の前 縁部に再び斜走線系 (3) の出現が認められる。また, 閶節突起稜の上部には線系（1）が体部のもの上分断さ れて一部残っているのが認めら机る。（図了0,a.）

内側面観 group 3. 之ほぼ同様の所見であるが， group 3. K見られた不整裂線団（2）は，之の範囲 やや狭め，下顎切痕部辺縁に沿う線系（5）が新たに出 現している。また。下顎孔を取りまく一連の囲繞線系 (6)怔出現している。(図10，b.)

\section{Group 5 (生後 7 力月)}

外側面観 group 4. で出現した筋突起前縁部の斜走

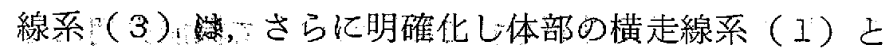
合し，とのため不整裂線団（2），（4）は再び上下に 2
分されてその領域屯縮少されている.（図1.1. a.）

内側面観 group 4. で見られた線系 (5) はさらに 明確化し，不整裂線団（4）は下顎枝中央部にその領域 を狭めている，また，筋突起前縁部の斜走線系（3）の 一部は体部の横走線系（I）と連なり不整裂線団（4） の限局化が目立っている。（図11。b.）

Group 6. (生後 8 力月)

外側面観 前期に比して下顎枝全面に線系化の傾向が 著明に認められる。すなわち, group 5. で体部の線系 と合した関節突起稯に沿う線系（I）扣上び筋突起前縁 部の斜走線系 ( 3 ）は, さらに明確化し, その範囲を広 めている、したがって，不整裂線団（2），(4) は，そ の領域を狭め, 角突起下縁部上下顎枝中央部よりの下顎 切痕部に限局されて見られる。 また，この期では，不整 裂線団（2）の前下方の下顎枝後縁隅角上部上り線系 (1) に直交的な短い線系（7）が新たに出現し，さら に, 筋突起後縁上部に該縁に沿う線系 (8) の出現が認 められる。（図12、a.）

内側面観 group 4.5. 亿打いて下顎切痕部辺縁に見 られた線系（5）は，乙の期に至りさらに増加し，不整 裂線団（4）は, 筋突起中央部の小領域に限局して認め られる。（図1.2， b.)

\section{Group 7. (生後 9 力月)}

外側面観 線系は，全体として整然化され，かつ著明 である。すなわち，下顎枝中央より下顎切痕部に限局 された不整裂線団（4）は，線系化の傾向を示し，筋突 起後縁より前方に広がり呞状線 系と化しているが，な 招線系の中に乱机が認められる。この期では，前期の group 6. よりさらに不整裂線団（2）はその範囲を縮 少し，角突起辺縁に限局している．また，group 6。 で 出現した線系（7）は再び消失する傾向を示し，わずか にその一部が認められる。しかし，乙の期に至り隅角部 中央に新たな不整裂線の小集団（9）の出現が認められ る. (図13，a.)

内側面観 group 6. よりさらに線系化の傾向が著明 で, 線系（1)，（3），（5）の3辺よりなる同心性の三 角形線紋化を示している，その中央部は縮少された不整 裂線団（4）にて充されている。（図13．b.）

$$
\text { 対 照 側 }
$$

\section{Group 1.}

外側面観 角突起下縁に沿う線系 (10') の前上方に 乱れ $\left(2^{\prime}\right)$, および筋突起後縁に求ける線系の乱机 $\left(4^{\prime}\right)$ が認められる。（図14. a.）

内側面観 筋突起部後縁に線系の乱れ (4') が認めら 
れるのみである。（図I4.b.）

\section{Group 2.}

外側面観 group 1. 之ほぼ同様の所見であるが，不 整裂線の筑园がやや増大している。

内側面観 group 1.。の側面観之ほ济同様であるが， 角突起部に線系の乱れ (2') の出現が認められる.

\section{G oup 3 .}

外側面観 group I. 2. で筋突起部に見られた線系の 乱机 $\left(4^{\prime}\right)$ 屯著明となり，下顎枝中央 部に向ってその範 囲を広げている。

内側面観 group 1. 2. で見られた線系の乱れ $\left(4^{\prime}\right)$ は，筋突起中央部へとその領域を広める詣向が認められ る.

\section{Group 4.}

外側面観 下顎切痕部にはえの辺縁に沿った線系

$\left(5^{\prime}\right)$ が出現する，不整裂線団 $\left(4^{\prime}\right)$ は，筋乫起中央部 に向ってさらにその笵囲を広げている。 また，解起 後縁に沿う線系 (1.1’') が新たに出現している.（図1.5. a.)

内側面観 不整裂線団 $\left(2^{\prime}\right)$ が角突起下縁に沿う線系 (J.0 $)$ によって前方上後方とに2 分される. 筋突起後 緣に沿う縦走線系 $\left(5^{\prime}\right)$ の新たな出現を見る他に，下顎

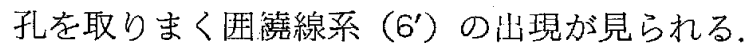

(図1.5. b.)

\section{Group 5.}

外側面観 group 4.で見られた線系 $\left(5^{\prime}\right)$ は，辺縁 および関節突起稜に沿う線系ととすに，咬筋窝を境する 三角形線紋を形成する傾向が見られる，また，その中心 部はな㧍不整裂線屉（4'）によって充されている。

内側面観 角突起部に見られた不整裂線団 $\left(2^{\prime}\right)$ が該 突起上部にのみ限局して認められ，角突起前方のあのは 消失し，下顎骨体部の横走平行線系（I'）に上って占め られている。

\section{Group 6.}

外側面観 三角形線紋は，さらに明確化し，その中央 部にはなお不整裂線団 $\left(4^{\prime}\right)$ を認めるのみである.

内側面観 group 5. とほぼ同様である.

\section{Group 7.}

外側面観 三角形線紋は，さらに明瞭となり，その中

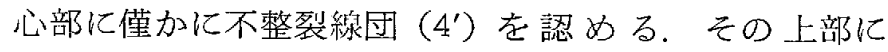
は，小範囲に限局した不整裂線団（2'）が認められる。 (図1.6. a.)

内側面観 group 6. とほぼ同様の所見を示している が,さらに線系化の傾向が著明である。（図16. b.)

\section{総括および考察}

対木40)（1950），その他が実験した咬筋の一部剥離と ことなって，咬筋の完全切除は繁雑で発育時の幼犬に加 なりの手術的障害を与えるものと考えられる. しかし， 麻酔法の改善, 手術時期の選択などで, ある程度の軽減 がなされ得る．実験犬は手術翌日より，不自由ながらも 対照側で食べるが，経日的に創傷の治瘾に従い食事に不 自由さが見られなくなり，完全治癒する10日前後では， 飯, 魚, 固型飼料などの食事には, 外観上非実験犬とほ とんど変り無い咀嚼観を示している．したがって，術後 数日は，手術の障害があってもそれ以後の発育，上く に, 下顎骨の発育成長は，咬筋の切除による機能障害に よるものと考えてよいだろう。

当初, 咬筋切除部には，他の咀嚼筋上り若干の代償性 增殖発育を想定したが, 肉眼的には全くかかる徽侯，お よびその他の異常が見られず，代って液状に富む結合組 織で充されているのが，術後」カ月より7カ月まで認め られた。しかし，咀嚼笳の中でも最大の機能力をもつ， 片側の 咬筋の切除は，それだけで他の咀嚼筋，すなわ ち, 同側あるいは対照側の咀嚼筋に, ある程度の機能負 担が吅重されるはずである。したがって，肉眼的な変化 が識別出来なくとも，分裂線所見で見られた機能的防禦 反応之考えら拓る不整裂線の出現，およびX線所見で見 られた第 4 小罒歯や第1大臼歯の 根尖 1/3 辺の槽内中 隔が実験側に比し不透過性が増すことなどから，筋線 維群にも， ある程度の変化が 見ら机るものと考えられ る.

製骨標本に抢ける実験側下顎骨の形態変化は，角突起 および関節頭の退行性変化，すなわち，発育不全之下顎 枝におりる骨增生が著明な変化である。

角突起の 発育不全は，咬筋切除による機能形態の退 行性变化にほかならない，角突起の内側には，内翼突筋 が附着作用しているので変化もなささうに思われるが，

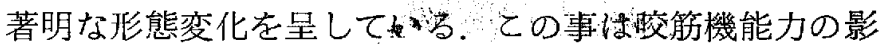
響がそれだけ偉大であることを示している．かかる退行 性変化によって，内翼突筋の附着部はわず加に上方に移 動し，下顎孔直下部までにおよんでいる事は興味梁い。

下顎枝の骨増生は，角突起招よび隅角部の退行性異常 形態に対抗する生理的な防禦反応の現われで，咬筋切 除による機能力に応じた下 顎枝 中央 部の増築之解釈す る，かかる骨增生は，group ]。においてすでに現中 れ，経月的汇増大し group 6。侄ると，当初粗造な面 を呈していた増生骨面もすでに平滑化して機能失調に相 応した形態を整えている，汃るる現象は，X線的にもそ 
図 7

a . 外側面钼

図 8
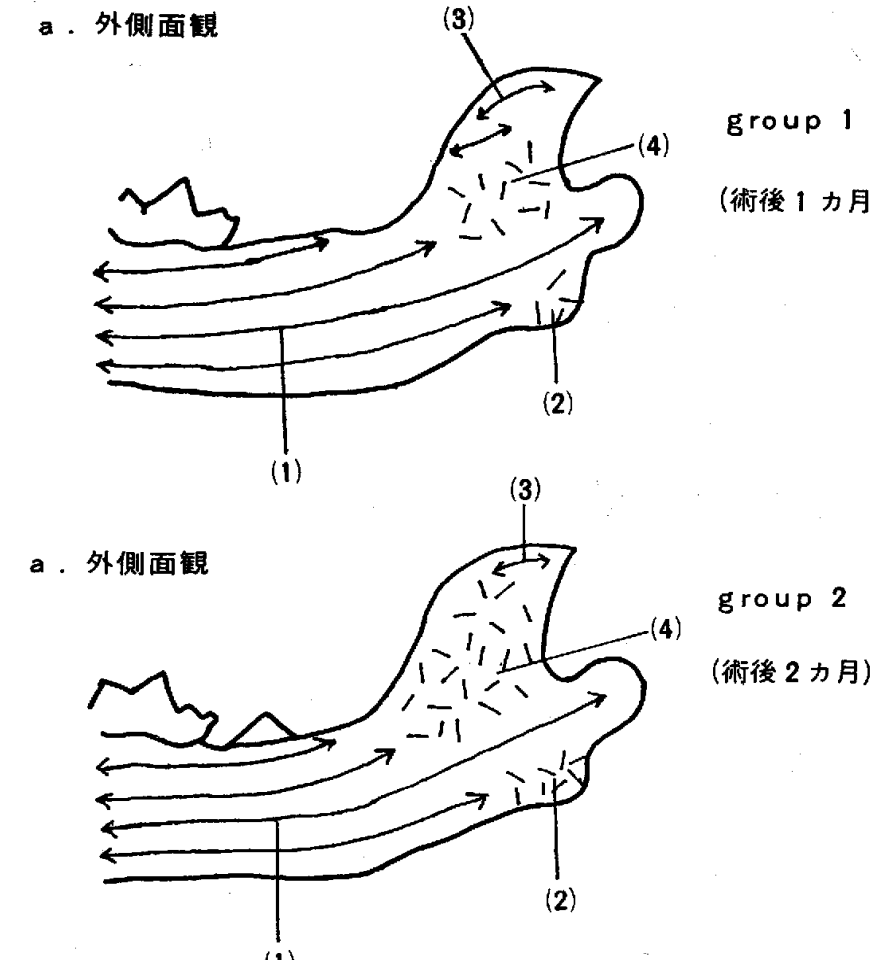

(1)

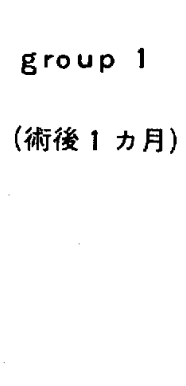

[実 験 側]
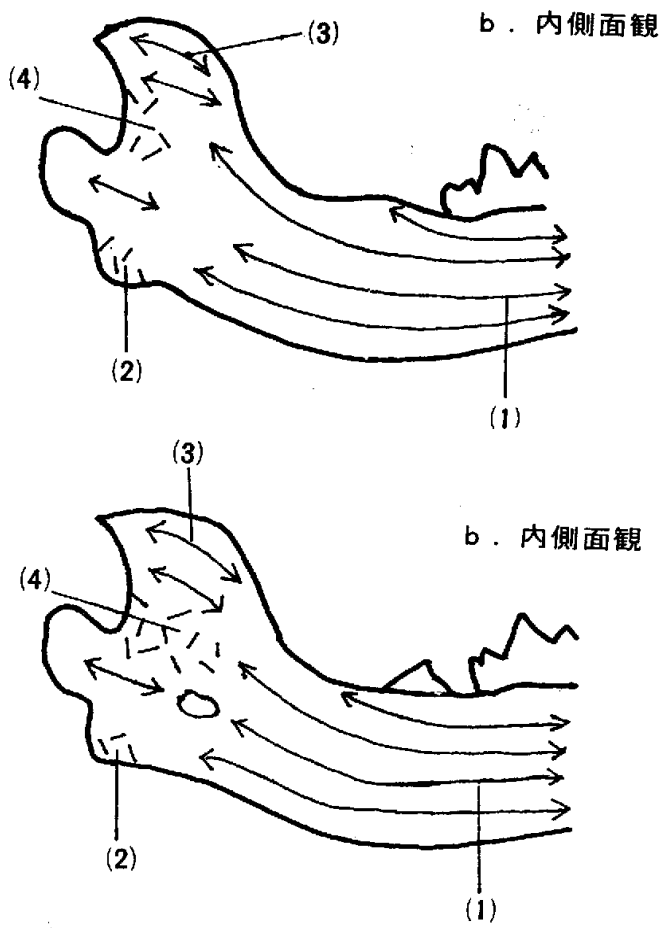

图 9
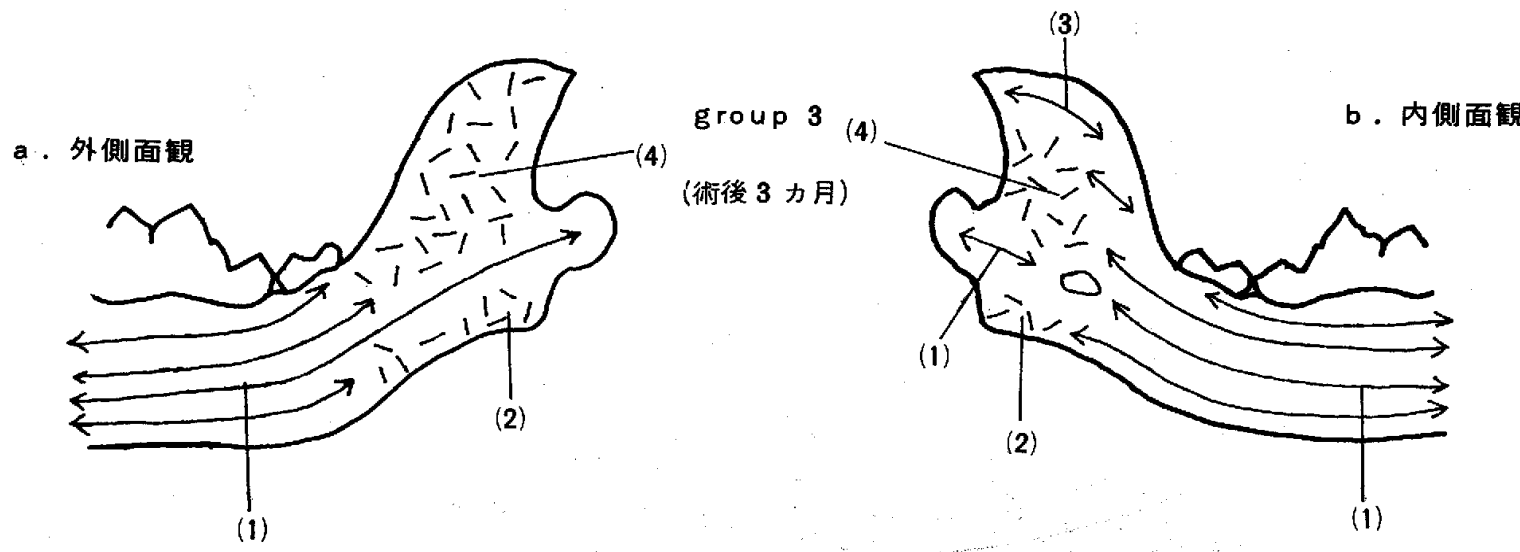

図10

図11
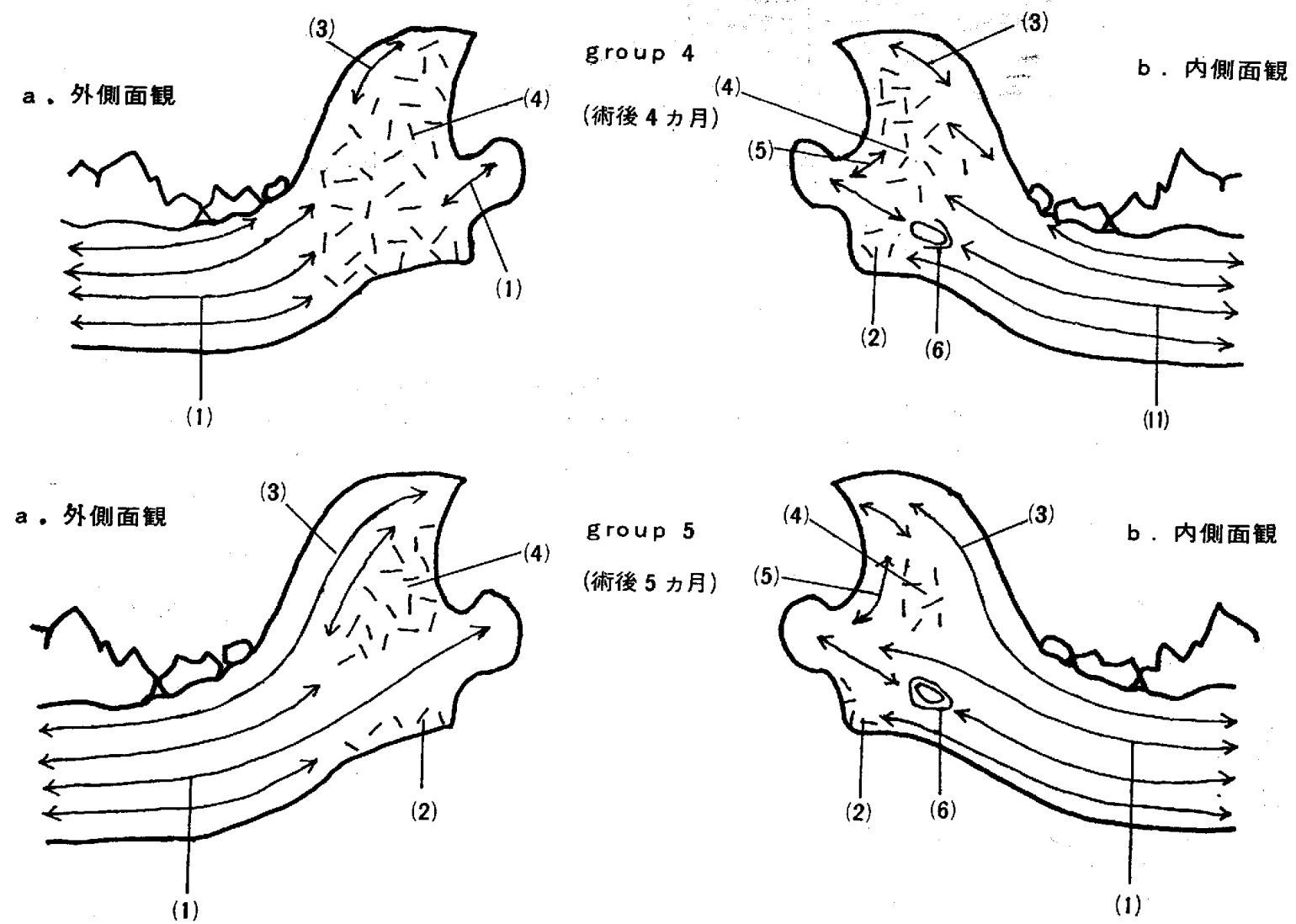

図 7〜13 group 1.〜7.にいたる実験側の分裂線. a. 外側面観. b. 内側面観. 
图12

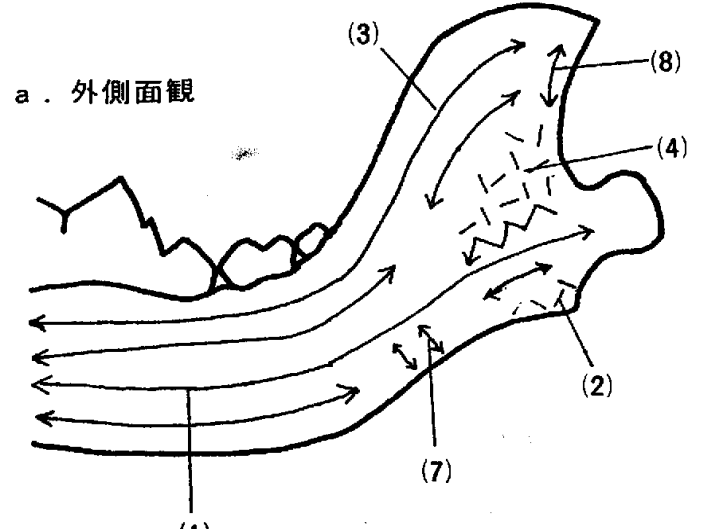

图 13

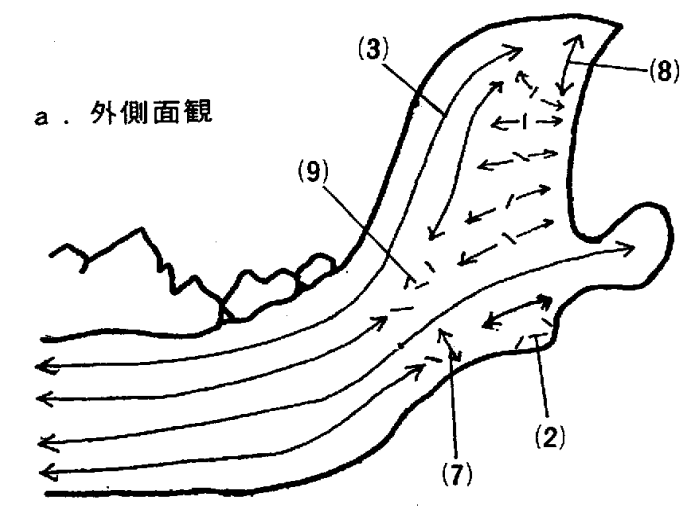

図 14

図15
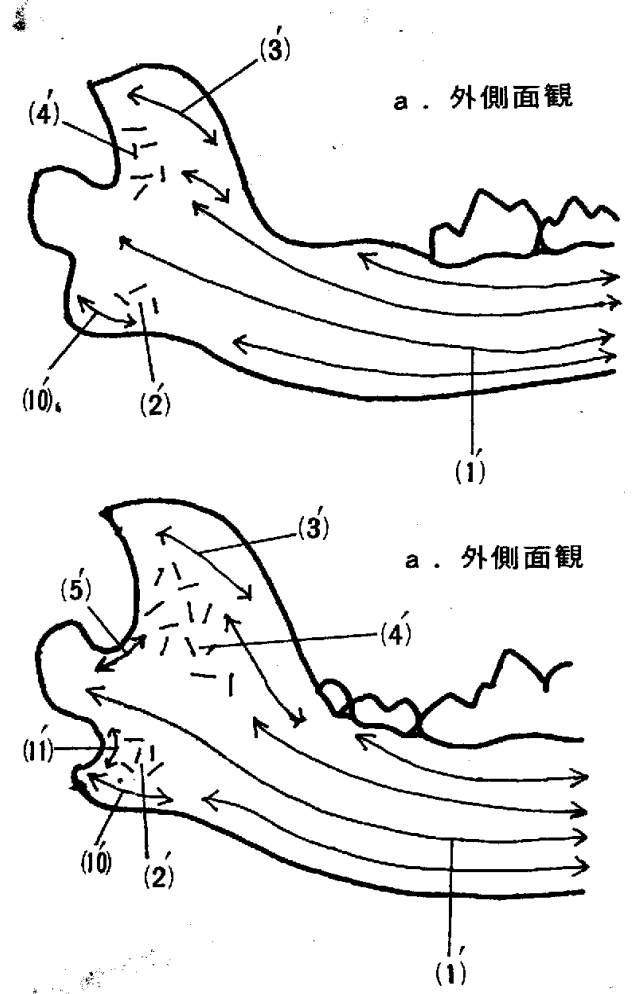

図16

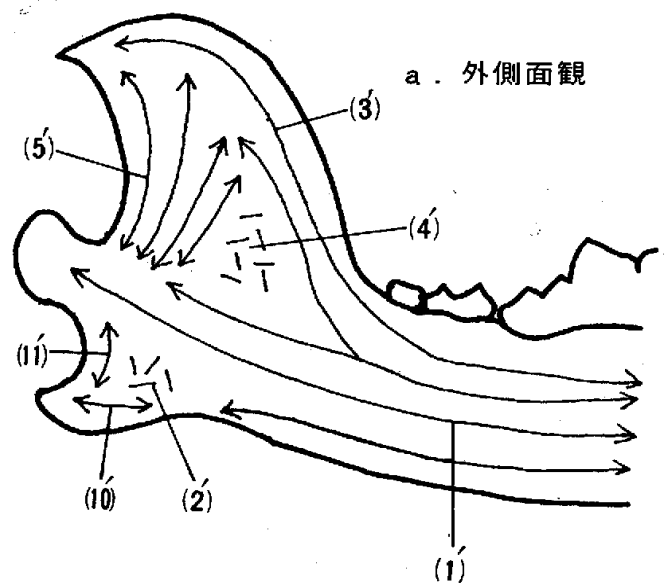

group 6

(術後 6 力月)

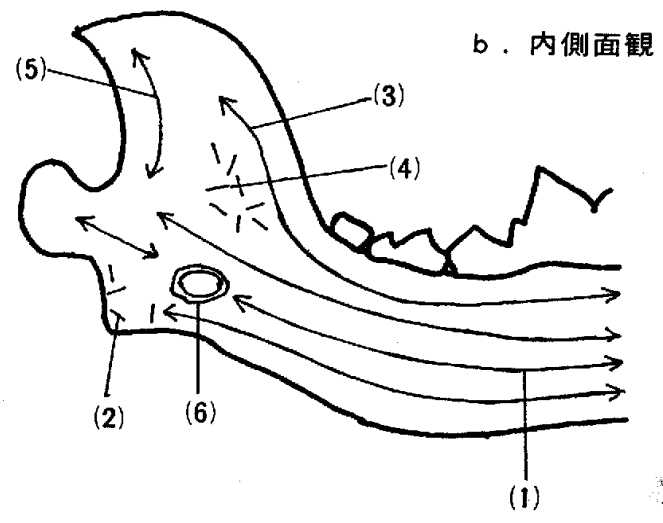

group 7

(術後 7 力)

[対 照 側]
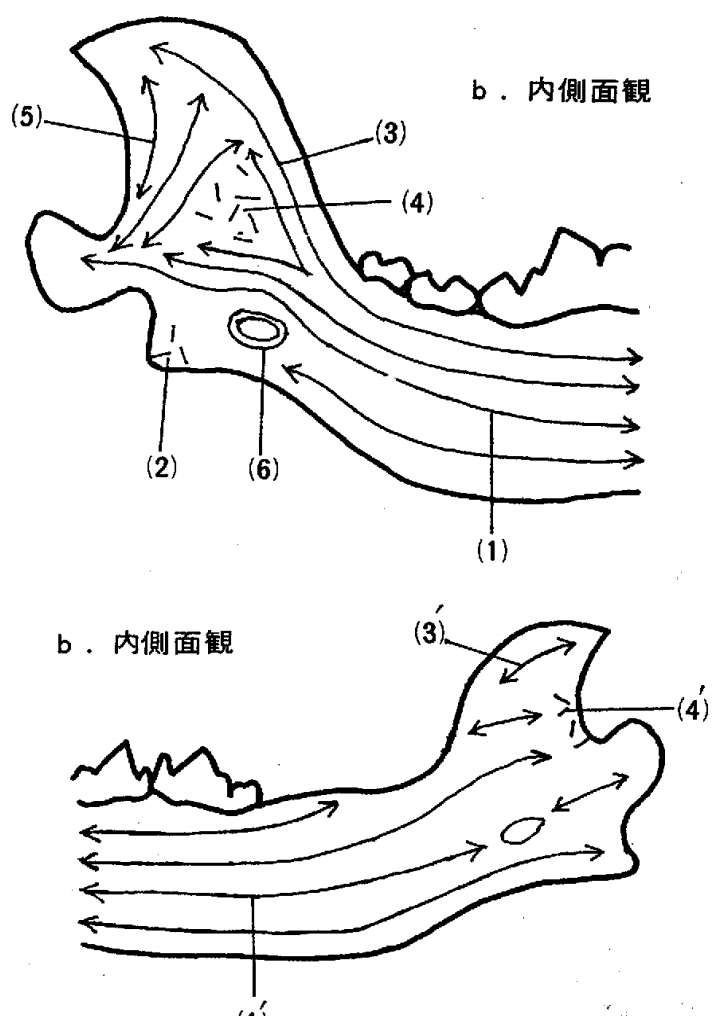

(1)

b . 内側面観

group 4

(術後 4 力月)

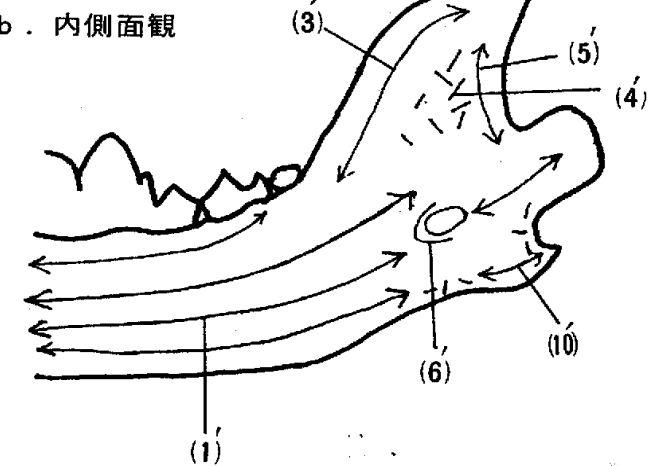

group 7

(術後 7 力月)

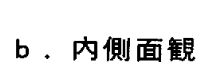

内側面観

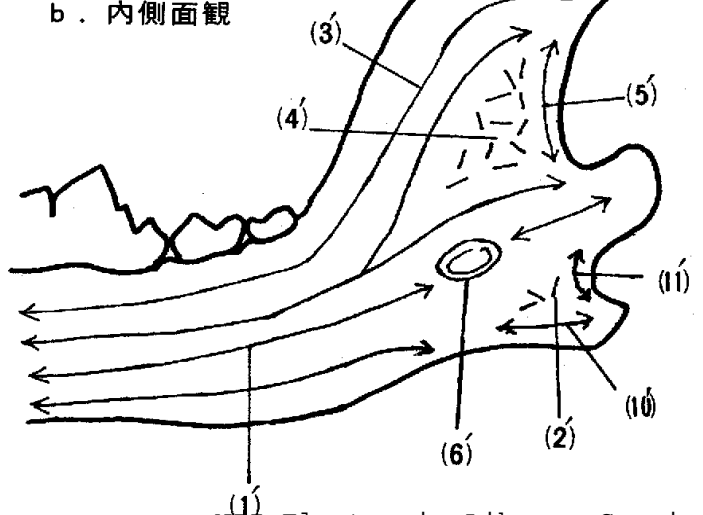


の徵侯が現われる，すなわち，奏験側咬筋窝は，当初， 骨柱がやや疎にして不規則に配列しているが経月的に骨 増生に伴い，漸次不透過度をましている。

関節頭の発育不全，上くにその長径的縮少も機能力の 減退に伴う一種の形態変化と考えられる. この部の変化 に関しては，計測的観察において著明に現われている。

永久荬列の所見として，実験側，対照側とも歯牙の萠 出状態にほとんど差は無いが，本来成犬において見られ る小曰歯部の歯間間隙の形成が興 味深く観察された. すなわち，永久歯列萠出完了後，しばらくは拉互い（ 小，大曰歯）の歯冠が相接触しているが，対照側では術 後 5 カ月より，実験側では 6 カ月より小曰歯部の畨間間 吵形成がみられる。この事は，実験側が対照側に比して 下顎骨の前後的発育の劣っていることを物語るあのであ ろう．従来から，下顎骨の後方発育（後で詳述）は，歯 列弓の拡大によるといわれているが32,38)歯列弓の拡大は 咬筋の機能力にも影響をうけているととになる。なお， 井尻（1962）12) は，歯牙萠出時期は䋶の成長の速さによ り規定されると述へているが，てれを裏付ける計測 值，X線怙よび分裂線的所見はともに見い出せなかっ た。

\section{計測結果についてみるに}

差の検定には $\mathrm{t}$ 一分布を用い，各 groups ぞとに実験 側之対照側の平均值の差が有意であるか否かを判定し た。（表 3）しかし，その差がかなりある場合でも有意 差が認められない事は，標本のばらつきが考えられる. 例えば，if-goc の計測項目における group 2。をみ るに，その差が 9.67mm あるにあかかわらず $\mathrm{t}$ 一值は 1.. 3295で有意差が認められない（この事は，左右側平 均值の差が無いのとは意味が異なる。）したがって，各 計測結果, 有意差が認められるあのは，その差がとくに 著明であり，有意差が認められない場合であその差があ れば対照側に比し増加傾向あるいは減少傾向を示すと解 されるむのである。

下顎骨長径発育は, 各計測とむ if-crc の group 1 . を除き対照側に比し距離の短縮を孔，とくに，角突起部 までの長径における差が著明である，乙机は，咬筋切除 による角突起の著しい退行性変化, すなわち, 発育不全 によるもので当然の結果である，また，関節頭外側点ま での, 長径は内側点までの距離よりも比較的著明な差 がみられる事は，咬筋切除による機能力減退に 伴う形 態的変化とともに, 他の咀嚼筋の代償性機能により実験 側が対照側に多少率引される咀嚼運動の異常により招来 された機能異常による刺激性変化の結果と考えられる。
また，その外側面の変化により，計測点の位置は関節頭 の形態からして近心側隹移行するためである.

下顎枝高径に押いては，関節頭よりあ角突起加らの高 径が対照側に比し著明な差, すなわち，距離の減少がみ られる。この事は, 長径発育でも述べたように角突起部 の発育不全によるあのである.

関節頭長径において屯, 対照側に比し距離の短縮がみ られ，長径発育で述べたように関節頭外側面の萎縮によ る結果である.

筋突起幅径む左右側の差が group 4. より比較的著 明に現われ距離の減少を示している事は, 下顎骨長径発 育の距離の減少と同様, 筋突起の後方発育の遅延を示し ている.

下顎骨体部の高径は，小毛雪部にては距離の減少を み，大白歯部では逆に増加を示している. 小曰歯部の発 育は，㑡頭筋の機能力および，歯胚の発育によりなされ るといわれているが，本実験に打いては，計測所見で述 べたように距離の減少をみることから咬筋の機能力も多 分に影響する事が考えられ，また，X楾所見に抬いて 屯，実験側が対照側に比し該部の透過度が高く，骨柱の

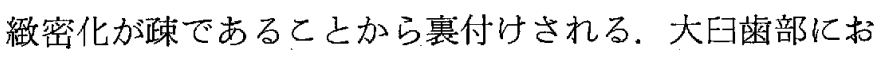
いてあその傾向が著明に現われるはずであるが，角突起 および隅角部の退行性変化による発育不全のため生理的 防旿反応の現われとして，骨が添加增生する結果距離の 增加をみるむのと考えられる。

筋突起角の桩大は，筋突起の後方発育不全の現方れた 結果である.

下顎体角，切歯縁高の左右側の差はいずれも著明で， これらはいずれす角笑起の発育不全による結果である。

関節頭傾斜角は，関節頭長径で述べたように計測点の 近心移動の結果, 角度の狭小を示するのである.

group ]. Kおける計測項目 if-crc は, 他の groups において距離の減少を示しているのに反し増加している が, この差はわずかで, 正常な下顎骨の左右側の差と大 して変りないため特に考察は加えない.

分裂線所見についてみるに

術後工力月（生後 3 力月）上り術後 7 力月（生後 9 力 月）までの実験側外側面および内側面, さらに対照側の 内, 外雨側面に打ける分裂線の状況乙比較検討するに。 本来健康犬の生後 6 力月頃までは下顎骨体部では横走平 行線系 (1), 下顎枝部では斜走線系（3）を示し, とくに不整裂線の出現は認められない30). しかし，咬筋 切除実験では術後工力月（生後 3 力月）において図 7 .

a. b. 抢よび図 14，a，b， に示すごとく，実験側外側 
面においては，角突起部に線系の乱れ（2）が認められ る。さらに晈筋窝を中心とする下顎枝中央部には著明 な不整裂線団 (4) 汃認められ，内側面においても角㔖 起，下顎枝部に拁いて線系の乱れ（2），(4) が認め られる，さらに対照側においてす，ての期においてすで

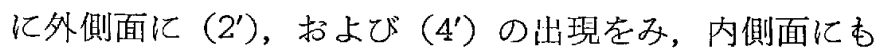

(4') が認められる. かくのどとく出現した不整裂線 は，咬筋切除によるもの上考えられる。すすなわち，角突 起部における線系の乱れ（2）は，咬筋に上る生理的刺 激が加わらないためとの部の 骨に発育阻害を来たし, 一定の発育方向が乱された結果出現したもの之考える. また，咬筋窝を中心とする部に著明に見られる不整裂線 団（4）の出現についても同様のことが考えられ，しか あとの部に広く認められるととは該部が陵筋による生 理的刺激を特に広域に受けているあのであろうと考えら れる，換言すれば，骨の発育方向に相応し，筋力による 機能的運動が調和を保つととによって下顎骨自体の発育 を正常ならしめるものと思わ机る，また，内側面の線 系の乱れ (2)，(4)，抢よび対照側の外側面 $\left(2^{\prime}\right)$, (4') 亡内側面の (4') の出現は生後3カ月ではすでに 咀嚼機能力が 発現しているもの上考えれば，筋切除 による咀嚼機能の低下を補うべく側頭筋 およよび内外翼 突筋の異常な収縮搽引によって出現したもの上考え る.すなわち，てれは骨質自体が示すところの外力に 対する一種の機能的防禦反応であると解することが出来 る.

さらに, 術後 2 カ月 $~ 4$ カ月と漸次不整裂線団の出現 領域が拡大している。これは，咀嚼機能むその活動が活 発となり，下顎骨自体の発育もきわぬて旺盛な時期であ ることから当然の事と考えられる。術後 4 力月に至って 関節突起稜に沿う体部の線系（1）份断され，不整裂 線団（2），(4) は合し, その領域は最大となっている が, 反面, 筋突起前縁部に再び線系 (3) の出現と内側 面の下顎切痕部に新たに線系（5）が出現し，また対照 側においてむ同様の所見が認められるとてろから，術後 1カ月〜 3 カ月まで発育阻害期（防禦反応期）上呼ぶ ならば，この期は，転換期とも考えられるべきである。 すなわち，筋切除による咀嚼機能の直接的障害が他の咀 嘅筋により代償され，再び骨自体の発育方向が示現する 特期之考えられる。

術後 5 力月， 6 カ月に抢いては，線系化の傾向はさら に進み，不整裂線団むその領域を狭め，線系自体屯明確 化している。術後 6 カ月において, 下䫟枝後縁の隅角上 部より線系（1）に直交的な線系（7）の出現が新たに
認められる。乙れは，焧筋切除による骨の発育阻害（と くに下顎枝抢よび阳角部）によってとの部に幅径の減少 をみたが，乙の期より増加するととを示したものと考え る.

術後 7 カ月に至っては, 対照側を含めて内外両側と屯 前期に比し，さらに線系化の傾向は著明になり不整裂線 団（4）は扇状線系（8）を示す傾向にあるが，なお， その中に乱れが散見される. 前期に招いて認められた線 系（7）は，その領域を狭減少している。 また（7） の上部にわずかながら不整裂線（9）の出現を新たに見 るが，これは，著明な発育度を示して来た線系（3）上 （1）との内的発育の衝突に上り出現したもの上考え る. したがって, 術後 5 カ月〜 7 カ月は, 阻害された発 育が再び発育方向を定着する時期，すなわち，再発育方 向定着期とも考えられる。

Shapiro (1938) 32)，滝本 (1.958)38) は猫に打いて，下 顎骨の後方発育が 歯列弓の拡大によりなされると報告 し, また, Landsberger (1923)19), 堤 (1953)41,42), 雨 森 (1964)1) 等は，歯胚摘出か靧骨の形態発育に影響す ることを実験的に証明している。一方，Shapiro (1939) 33), 高橋 (2936)33), 対木 (1950)4J), 斎藤 (1939)31) 等 は，歯胈の発育は下㖽骨の発育に全く影響しないと報告 し, さらに, Blumenthal (1934)4) は, 臨床例より菌肧 と顎詧育が必ずしも一致しないととを報告している.

ここで, 雨森, 堤の実験結果を見るに, 雨森は, 下顎 骨長径 $(0.48 \%)$, 筋突起高径 (1.33\%), 関節頭長径 (4.73\%)，そ机ぞれ距離の減少するのに反し，下㖽枝 高（0.67\%）は増大したと述べている.

一方, 瑅は長径 (2.2\%), 関節 頭長径 (10\%)，それ ぞれ対照側と比し距離の減少をしたと報告している.

堤の値は, 雨森の計測法と異っているため, 左右側の 差が比較的著明に現われている。 そこで雨森の計測にて 行えば, 長径1.01\%, 関節頭長径 $2.58 \%$ になる.

以上の報告之著者の結果を比較すると, 長径（1.88 $\%)$, 筋突起高径 (5.44\%), 関節頭高 (7.07\%), 関節 頭長径 (6.52\%) それぞれ距離が減少し, その差は前記 の報告と比し著朋である.

この実験の結果よりすれば，下顎骨の形態発育は機能 形態之断定され，下顎骨の発育に抢よぼす影響は歯怔の 発育より，筋の機能力による方がはるかに大きいといえ る.

片側咬筋の完全切除による咀嚼筋の機能失調が下顎骨 の形態発育にいかに影響するかを犬を用い実験的に研究 
した.

実験に供した犬は，生後1.5〜 2 カ月（1.5〜3.2kg） の幼犬で左側を実験側, 右側を対照側とした。 40例の犬 を飼育期間 Iカ月から 7 カ月（group 1.〜7。）までの 7 groups K分けて, 肉眼的, $X$ 線的, 計測的, 分裂線 法的に総合観察を行なった。

その結果は, 次のごとく要約される.

1. group 1. の実験側は, 咬筇窩拉よび関節突起稜 部に骨の増生が見られる。該部は，X線において骨柱 が不規則に配列するととあに緻密化が疎であり，分裂線 においては不整裂線として現われた。骨増生は経月的に 増加し, group 4. で最高を示し, X線では不透過像の 増加，分裂線に括いては不整裂線の範囲が拡大してい る.しかし， group 5.〜7.になると対照側に似て骨面 は滑沢化する傾何を示し，X線では不透過像がさらに増 し，分裂線では不整裂線が線系化している.

2. 歯牙の萠出は，左右側に差はないが，小目歯㐘間 間隙は，対照側よりも遅れて形成され，X線において は, 第 4 小臼歯, 第了.大臼歯槽内中隔部に抬ける透過度 が対照側より增している。

3. 下顎骨の前後的長径 (if $-\mathrm{cd}, \mathrm{cl}, \mathrm{cm}, \mathrm{goc}$, $\mathrm{crc}, \mathrm{crd}$ ), 筋突起高径 (crd-gov, cd-crd), 関節頭高 径 (cd-gov, cl-gor, cm-gov), 関節頭長径 (cm$\mathrm{cl}$ ), 下顎体角, 関節頭傾斜角, 小四歯部骨体高径 ( $\overline{\mathrm{aP}} 2$ $\left.-\mathrm{a}^{\overline{\mathrm{P}_{2}}}, \quad \mathrm{a} \overline{\mathrm{P}_{3}}-\mathrm{a} \overline{\mathrm{P}_{3}}, \overline{\mathrm{aP}}_{4}-\mathrm{a}^{\overline{\mathrm{P}_{4}}}\right)$ は各 groups と屯対照 側に比し距離あるいは角度の減少がみられ，とくに， if-goc, crd-gov, cd-gov, cl-gov, cm-gov, cm - cl，下顎体角，関節頭傾斜角などが著明である.

大臼雪部骨体高径, 筋突起角, 切歯縁高は, 各 groups とも逆に増加している。

以上のごよき長径招よび角度の変化は筋切徐による機 能的形態の現われであり，石灰化の遅延および歯列弓の 拡大のおくれ姑下顎骨の発育の悪さを示すものである.

下顎枝部ことに咬筋墖や関節突起稜执よび大日㐘部の骨 増築は筋切除によりひき起された生理的防禦反応を物語 るあのである.

稿を終るにあたり御指導, 御校閲をいただいた坪根政 治教授ならびに三枝博教授に深甚な謝意を捧げると共 に, 終始御助言いただいた中山種秋教授，山田博教授， 島村昭辰助教授, 村上守良講師およびロ腔組織学教室員 各位に心から感謝します。

\section{引用および参考文献}

1. 雨森 洋; 歯牙の欠損に上る頭蓋骨の形態変化に関 する実験的研究：口病誌，32，1-60，(1964).
2. Avis, V.; The significance of the angle of the mandible an experimental and comparative study : A. J. Phys, Anthrop, 19, 55-62, (1961).

3. Baker, L. $\mathbf{W}$.; The influence of the formative dental organs on the growth of the bones of the face: A. J. Orth. and Oral Surg., 27, 489-506, (1941).

4. Blumenthal, F. R.; Dental abnormalities for the orthodontists consideration: I. J. Orth. and Dentisty for Children, 20, 1145-1165, (1934).

5. Chales, H. M.; Tooth forms and masticatory mechanisms of natural and artificia! teeth: $\mathrm{J}$. Prosth. Dent., 19, 22-35, (1968).

6. David, J. S. ; The mandibular lever : J. Prosth. Dent., 19, 342-349, (1968).

7. Friel, S. ; Muscle testing and muscle training : I. J. of Orth., 11, 337-361, (1925).

8. Friel, S.; Occlusion observations on its development from infancy to old age : J. Orth. and Surg., 13, 322-, (1927).

9. 後藤信男, 森 彰; 家畜成長に伴う骨の分裂線の変 化，I，羊下顎骨について：会津短大学報， 24, 15-31., (1967).

10. Hildebrand, G. Y.; A further contribution to mandibular kinitics: J. D. Res., 16, 551-559, (1937).

11. Howe, P. R.; The influence of food on malocclusion : I. J. Orth., 13, 199-206, (1927).

12. 井尻正二他 : 犬の歯の萠出時期 : 解剖学雑誌, 37 , 331-338, (1962).

13. 今井倭武; 家畜の下顎骨について, 家畜解剖学の補 遺 (その7) : 獣医畜産新報, 166, 8-11, (1955).

14. 今井倭武; 家畜の下顎骨について, 家畜解剖学の補 遺 (その 7) 続稿 : 獣医畜産新報, 174, 9-12, (1.956).

15. 石野恵庸; 人類下顮骨骨棱群について, その 2 . 生 後 4 力月から高令80才にいたる日本人の下顎骨骨稜 群の増令的発育動向に関するX線学的研究：三重医 誌, 35, 193]-1948, (1960)

16. 上条雍彦; 口腔解剖学. 1. 骨学 (頭盖骨学), アナ トーム社 (東京), (1966).

17. 小山次男 ; 大腿骨骨折の治癒機転に伴う分裂線の変 化に対する実験的研究，第工編，Kuntscher 氏䯣内 固定に於ける場合の変化：熊本医誌， 30, 133- 
140, (1.956).

1.8. 小山次男 ; 大腿骨骨折の治癒機転に伴う分裂線の変 化に対する実験的研究. 第 2 編. 変形治癒骨折に おける場合の変化：熊本医誌，30，141-148, (1956).

19. Land'sberger, R.; Histologische Untersuchungen über das alveolare Wachstum in seiner Beziehung zur der Entwicklung des Zahnkeims: Deutsche Monatsschrift für Zahnheilkunde, 14, 417-429, (1923).

20. 松元 誠; 下顎大曰歯扔よび小田歯欠損後の下顎骨 の形態学的変化：日本蒾科学会誌，28，271一290, (1961).

21. Mauer, G.; Untersuchungen über funktionelle Anpassung der Wirbersäule bei Skoliose : Beiträge zur Anatomie Funktioneller Systeme, 1, 412, 420, (1933).

22. Miller, M. E. ; Anatomy of the dog: Saunders (London), (1967).

23. 水島治夫; 簡約統計学: 南江堂 (東京), (1963).

24. 森 忠男; 本邦産雑種犬に於ける歯牙形態及び其の 二代歯列発生の時期に就て：日本歯科学会誌，22, 227-256, (1930).

25. 長會義夫; 犬の疾病学, 内科伝染病 : 医歯薬出版, (1961.).

26. 中山種秋; 骨分裂線特に不整裂線の意義：九歯学会 誌, 11，1-14，(1957)。

27. 織田健太郎; 下顎骨の形態学的研究 : 日本口腔科学 会誌, 19, 1-37, (1937).

28. 㦄 春木; 酢酸鉛生体染色法による顎発育に関する 研究，第工編，上顎の発育; 口病誌，17，36-46, (1.943).

29. 育藤弘吉; 犬科動物骨格計測法, Osteometric der Caniden wie ist das Skelett der Caniden zu Messen : 東京, (1963).

30. 佐藤信正; 犬下顎骨の発育に伴う分裂線の変化に就 いて : 九崡学会誌, 12, 177-185, (1958).

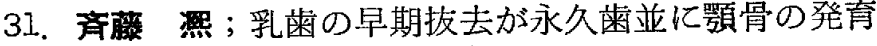
に及ぼす影響に就いての実験的研究：口病誌，13, 124-134, (1939).

32. Shapiro, H. ; Growth in dental arch of the cat : J. D. Res., 17, 349-337, (1938).

33. Shapiro, H.;Experiments dealing with factors influencing the shedding of deciduous teeth : $\mathrm{J}$.

D. Res., 18, 73-79, (1939).

34. Snedector, G. W. ; (烟村又好他共訳); 統計的方 法改訂版：岩波書店（東京), (1962).

35. 杉浦信男; 骨格発育 抑制の実験的研究 (会) : 日本 整形外科学会雑誌，17，453-458，(1942).

36. 高橋新二郎; 歯牙交換の研究 : 口病誌, $10,1-35$, (1936).

37. 高橋新二郎，榎 惠; 犬の第工小田歯は乳歯なり： 口病誌, 17, 218-226, (1943).

38. 滝本和男; 顎発育之歯列弓の変化に関する実験的研 究：口病誌，7，138-159，(1958).

39. 高田則義 ; 犬頭蓋骨緻密質の力学的構築に関する研 究: 久留米医誌, 22, 2881-2895, (1960).

40. 対木桂次; 犬に书ける下顎骨発育の実験的研究：倉 敷中央病院年報，21，44-60，(1950）。

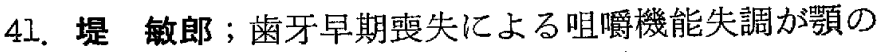
発育に反ぼす影響に関する実験的研究，(完）：歯科 学報，53，546-550，(1953):

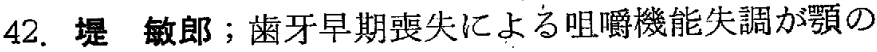
発育に及ぼす影響に関する実験的研究：歯科学報, 53, 499-504, (1953).

43. Tweed, C. H.; Indications for the extraction of teeth in orthodontic procedure: A. J. Ortho. and Oral Surg. 30, 405, (1944).

44. Weinman, J. P. and Sicher, H.; Bone and bones : Fundamental of bone biology, St. Louis, Mosby, (1955).

45. 吉川徹男他; 哺乳類咬筋の比較解剖学的研究 : 解剖 学雑誌, 36,53-71, (1961). 